\title{
BROTHERS IN THE KITCHEN: \\ THE UPRISING, EXODUS AND SURVIVAL OF A TAMIL MINORITY
}

by

Cyrus Sundar Singh

\author{
A Major Research Project \\ Presented to Ryerson University \\ In partial fulfillment of the \\ Masters of Fine Arts Degree \\ In the Program of \\ Documentary Media
}

Toronto, Ontario, Canada 2016

(C) Cyrus Sundar Singh 2016 


\section{AUTHOR'S DECLARATION FOR ELECTRONIC SUBMISSION OF A MRP}

I hereby declare that I am the sole author of this MRP. This is a true copy of the MRP, including any required final revisions.

I authorize Ryerson University to lend this MRP to other institutions or individuals for the purpose of scholarly research

I further authorize Ryerson University to reproduce this MRP by photocopying or by other means, in total or in part, at the request of other institutions or individuals for the purpose of scholarly research.

I understand that my MRP may be made electronically available to the public. 


\begin{abstract}
Brothers In the Kitchen (BiTk), is a site-specific live-documentary performed with an audience inside a fully operational restaurant. The triumvirate of story, performance, and audience is used to create an interactive and immersive documentary experience incorporating oral storytelling, poetry, dance, music, archival materials and televisionall performed live. BiTk is the story of the uprising, exodus and survival of Tamil Sri Lankan citizens who fled a brutal civil war and sought refuge in Canada. The ethnic conflict, between the Buddhist Sinhala majority and the Hindu Tamil minority, sparked a mass exodus following the deadly riots of Black July in 1983. Subsequently, a staggering 300,000 Tamils found asylum in Canada. Soon an inordinate number of them began work as cooks and dishwashers in many Canadian restaurants. This livedocumentary is performed thirty years after the arrival of the first boatload of Tamil refugees, found adrift off the coast of Newfoundland, in 1986.
\end{abstract}




\section{ACKNOWLEDGEMENT}

"can you and $i$ and we save the world?

we can certainly create moments magical and unique

where we may dance and swim naked again."

...long live the fish!

There are times when disparate parts coalesce into a tangible sum and the outcome seems almost predestined. Such was the case that has brought me to this final page of my Masters of Fine Arts (MFA) thesis. The trajectory to this juncture was not a direct line but a series of opportunities that have colluded, and persons who have guided me here. I did not always see nor seize the opportunity, usually out of self-doubt or a fear of failure. In fact, my "left turn" into the MFA was an attempt to run away from the failures of independent production. Fortunately, this "left turn" has served me abundantly and I have come through the academic fire fully rejuvenated. It was the best decision that I ever made. Over the past two years, I have been fully engaged, enriched, and enlightened by the knowledge I have gained, and I am privileged to do so.

Frist and foremost, I thank my partner, confidante, bread-earner, lover and muse, and Executive Producer Vanessa Laufer for guiding me towards the value of academia, this MFA, and for supporting me through this journey. I remain indebted to you. I also am indebted to our daughter Saskia through whom I continuously experience the depth and the breath of creating Art-our soul food.

My gratitude to all my Gurus at Ryerson who guided, nurtured, and challenged me throughout the program: Katy McCormick, program director; Don Snyder, primary advisor; Richard Lachman, second advisor; Marc Glassman, supporting advisor; Blake Fitzpatrick, Ed Slopek, Elle Flanders, Jason O'Hara, Vid Ingelevics, Elida Schogt, Dafydd Hughes, John Tarver, Min Sook Lee, and Samantha Wehbi.

In many ways this thesis and project would not be possible without the help of many hands in the Tamil community who supported my requests and inquires. I especially like to thank my two Gurus on the outside: Ravi Sumbramaniam, my muse, my guide, and the man who opened many doors into the community, and to Darshan Ambalavanar who, back in 2002 already encouraged by my filmmaking, imparted in me the wisdom that this was a story worth telling. Romba Nandri to you both.

Peace,

Cyrus

Toronto, August 2016 


\section{DEDICATION}

Dedicated to

the tenacity of all who seek safe harbour, hope, and home.

And to

ANONYMOUS,

who placed his trust in me to keep the story alive... 


\section{TABLE OF CONTENTS}

Author's Declaration.......................................................................

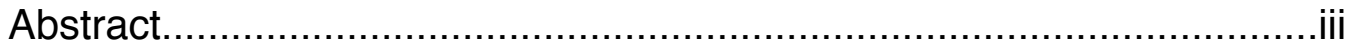

Acknowledgements............................................................iv

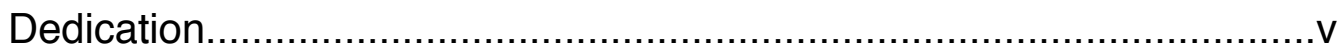

Table of Contents...................................................................

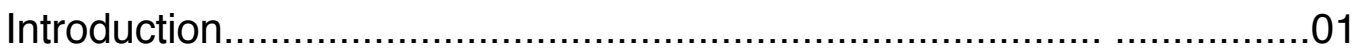

Brothers in the Kitchen.............................................

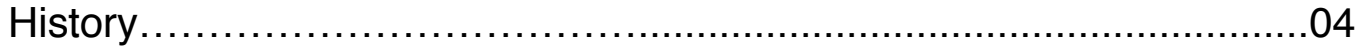

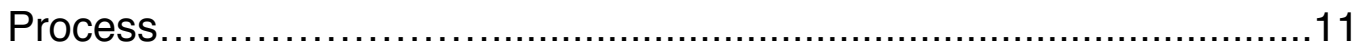

Container/Documentary Stew...............................................23

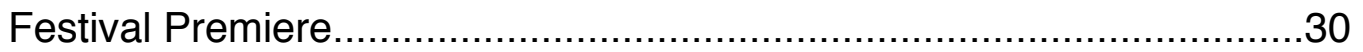

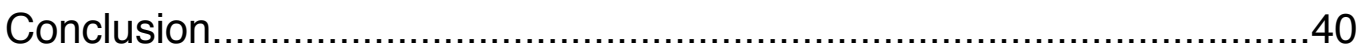

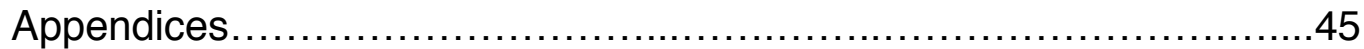

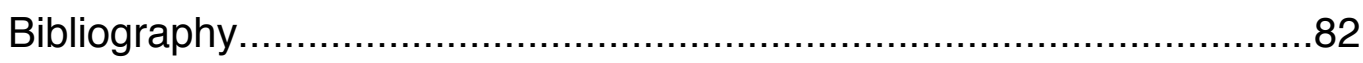

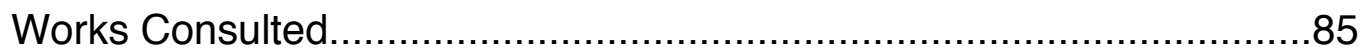

DVD Enclosure..................................... Inside Back Cover 


\section{LIST OF APPENDICES}

Appendix A - Performance Script.......................................46

Appendix B - Full Credit List............................................77

Appendix C - Press Links ............................................

Appendix C - Letter from Shane Smith................................79

Appendix D - Production Schedule.................................... 80 


\section{INTRODUCTION}

happy fish, happy fish, where have you been?

On August 11, 2016 near a small fishing village on the southern shores of Newfoundland, Canada, four former Tamil Sri Lankan refugees Shanmuga Paul, Gandhi, Siva, and Baskaran climbed into an old lifeboat and sat together. Overwhelmed by the moment, the four men broke down, cried, and comforted each other. This was the same lifeboat (one of two) in which, thirty-years ago, they (and others) were set adrift in the north Atlantic for days without food or water-no land, no help, no hope. Fortunately, on the third day they were rescued by a local fisherman.

That was the first time that all Canadians came face to face with "Tamils" and eventually became aware of their plight. They were the harbingers ahead of thousands of Tamil Sri Lankans who sought asylum from the brutal civil war fought along ethnic lines, and Canada was known to have a long history of providing safe haven for those escaping violence. Or did it?

As a young person, I too remember the dramatic arrival and rescue of the one hundred and fifty-five Tamils from those two lifeboats. It made national and international news. Three decades later, through my thesis project Brothers in the Kitchen, I explored the story of the Tamil Sri Lankans in Canada: the uprising, exodus, and survival of the Tamil diaspora. And in doing so, I had a hand in re-constructing that moment in the lifeboat.

happy fish, happy fish, what did you see? 


\section{BROTHERS IN THE KITCHEN \\ THE UPRISING, EXODUS AND SURVIVAL OF A TAMIL MINORITY}

Since the time our cave-dwelling ancestors recounted events of the day to those huddled round the campfire, we have been 'performing the documentary'. From the cave paintings of Lascaux to the dolphin frescoes of Crete, humans have found creative ways to document our stories to reflect the human condition. Stories are containers that hold memories, ideas, and hopes that we disseminate through various forms, styles, and media. The act of telling a story is a performance; every subsequent recounting is also a performance, a documented experience. And where there is a camera we perform to it.

In the late 1800s, with the advent of the movie camera, cinema was simultaneously a documentary and a performance. 'Actuality' films of the Lumière brothers, ethnographic reenactments in Robert J. Flaherty's films, the cinéma vérite of Jean Rouch and Robert Drew, and today's documentaries of Michael Moore and Morgan Spurlock', all suggest a continuum over time of 'performing the documentary'.

At the turn of the $21^{\text {st }}$ century, scholar Stella Bruzzi posited that "documentaries are a negotiation between filmmaker and reality and, at heart, a performance." $\mathrm{By}$ its nature, a film is both a documentary and a performance, and in the presence of an audience, it becomes a formidable tool. Once the audience connects to the story, they are ready and willing to be engaged, enlightened and transported-whether to the other

\footnotetext{
${ }^{1}$ Morgan Spurlock, in Super Size Me; a documentary film starring Morgan Spurlock. https:/www.youtube.com/watch?v=jAnCOHCVjyU

${ }^{2}$ Stella Bruzzi, "The Performative Documentary: Barker, Dineen, Broomfield," in Documentary: A Critical Introduction (Florence, US: Routledge, 2000), 154
} 
side of the mountain, the end of the earth, or into outer space. Therefore, the work at hand for the storyteller lies not necessarily in the "story" but in its "telling".

This constant search for new and interesting ways to engage the audience has been the impetus for some filmmakers to not only pursue story but also partner with technologies to expand the experience of telling those stories. Reflecting on this challenge, Bruzzi stated that “it's so hard to think, what can I do that's new?" ... "[H]aving said that, there's always something that is new." Various filmmakers have risen to this challenge: Morton Heilig's Sensorama ${ }^{4}$ machine with 3-D motion picture, and John Water's Odorama ${ }^{5}$ with its 'scratch and sniff' cards are two examples. Likewise, the immersive experiences of IMAX ${ }^{6}$, the personal 360 degree virtual reality glasses of the Oculus Rift ${ }^{7}$, and the move from analogue to digital, high definition (HD) to $4 \mathrm{~K}$ (four times the resolution of $\mathrm{HD}$ ) exemplify the chronic quest for new ways to tell stories whether screened inside cinemas, broadcast on television, or streamed onto handheld devices. It is within this context that my thesis, the site-specific livedocumentary Brothers in the Kitchen was formed with a view akin to telling a spellbinding story directly to a group of people gathered round a campfire. With the inclusion of food cooked, served, and eaten fresh during the performance, this livedocumentary's immersive experience was designed to play to all five senses: sight,

\footnotetext{
${ }^{3}$ Stella Bruzzi, "Taking the Pulse of Our Times: Media, Therapy \& Emotions," in International Workshop Video Interview (2014), Universidad de Navarra, Pamplona, Spain. https://www.youtube.com/watch?v=lcT9JiBY-OQ

${ }^{4}$ Scott deLahunta, "Sniffable Media." Performance Research 8 (3), (Routledge, 2003), 85-86. http://resolver.scholarsportal.info/resolve/13528165/v08i0003/85 sm.

${ }^{5}$ Ibid

${ }^{6}$ IMAX: http://www.imax.com/

${ }^{7}$ Oculus Rift: https://www.oculus.com/
} 
hearing, touch, smell, and taste. And I engaged these senses in the telling of this Tamil Odyssey.

More than a thousand years ago, a group of Vikings led by Leif Eriksson arrived on the eastern shores of Canada. ${ }^{8}$ They came by boat, exploring and seeking new opportunities. One could say they were Canada's first boatpeople. A millennium later, on Thursday, December 10, 2015 the Toronto Star newspaper ran the following frontpage headline:

"As 150 [Syrian] refugees land at Pearson today-among the first of 25,000- on behalf of the Star and our readers, we say: WELCOME TO CANADA."

It included a photograph of a young boy clad in shorts, sneakers and a Stetson gleefully waving a Canadian flag. An Arabic phrase was written and translated to English: "You're with family now." This front-page article, an informal welcome letter to Syrian refugees stated:

"And your presence among us makes our Christmas season of peace and joy just that much brighter [...] It's been a long trek, but you are no longer refugees $[\ldots]$ Your days of being strangers in a strange land are over."

By contrast, almost thirty-years earlier, on August 12, 1986 the Toronto Star ran the following headline:

More than 150 Sri Lankan men, women and children, found adrift off the coast of Newfoundland in crammed open lifeboats yesterday, arrived safely in port here this morning after being rescued by Canadian fishermen. As startled immigration officials here and in Ottawa pondered what to do with this unprecedented load of alleged refugees, the 152 castaways claimed they are Tamils fleeing persecution in strife-torn Sri Lanka. ${ }^{9}$

\footnotetext{
${ }^{8}$ Michael Valpy, "Strangers by sea: A tale of Canada's boat people", in The Globe and Mail, August 13, 2010. http://www.theglobeandmail.com/news/politics/strangers-by-sea-a-tale-of-canadas-boat-people/article1377063/

${ }^{9}$ Alan Story and Joseph Hall, "152 castaway paid thousands to flee to Canada", in Toronto Star, August 12, 1986.p1
} 
The words "alleged", "claimed", "startled" and "unprecedented load" are notable and markedly different from the tone of the Toronto Star headline of 2015. The Tamil refugees received significant negative media backlash. "People wrote letters in leading newspapers against the Tamil refugees. The main slogan was to "send the Tamils back to where they came from." One reader even went to the extreme by suggesting in his letter to the Toronto Sun that "the Canadian government should have sunken the lifeboats." 10

From Vikings to Syrians, Canada has a protracted history of people lured by the promise of new beginnings and bright hope, and those seeking refuge. Likewise, the circumstances and the welcome-or unwelcome-of new arrivals have fluctuated dramatically over the years. What changed between 1986 and 2015 that led to such a different reception of the Syrians and the Tamils? This change is only one part of what allowed me to successfully direct, produce and premiere the live-documentary, Brothers in the Kitchen, in a Toronto restaurant as part of Hot Docs Canadian International Documentary Festival ${ }^{11}$ in May 2016. But it took almost as long as the time between the arrival of the Tamils and the arrival of the Syrians described above, for me to create this documentary. Why was that?

I too arrived as an immigrant on Canadian shores and without doubt, my own search for identity is part of what originally drew me to tell this story of Tamil uprising, exodus, and survival. As a Canadian immigrant of Tamil descent, I grew up in Madras,

\footnotetext{
${ }^{10}$ Selva Ponnuchami, (Past-President of Elam Tamil Association of Quebec -ETAQ), in Monsson Journal, July 2016. https://issuu.com/monsoonjournal/docs/mj july 2016 web p18-19

${ }^{11}$ www.hotdocs.ca
} 
India, a place where coconuts kissed flaming hot curries and lovers met secretly amidst jasmine and humid sea breezes. As a small boy, I marveled at its streets bustling with colour, cars, music, shouting vendors and crowds awash in the smells of freshly ground cardamom and black pepper. As the capital of Tamil Nadu State, Madras (now known as Chennai) was steeped in Tamil language, culture and tradition-ancient and distinct. However, as a youngster I had little appreciation for these roots and was elated to learn that my family would be moving to Canada, the 'land of milk and honey.'

On arrival in Toronto as new immigrants, there were virtually no other Tamil speakers, save a family here or there. I quickly forgot my own roots and delved into a new life and fresh beginning. My link to my place of origin was little more than the food, the clothing and my brown skin. But suddenly, in the late 1980s, I began to hear my mother tongue on the streets, buses, streetcars and subway platforms of Toronto. The accent was a bit different, some expressions a little strange, but it was my language nonetheless. It was spoken by large numbers of refugees who had recently arrived from Sri Lanka, the jewel at the tip of India's necklace.

I had been taught that Indian Tamils spoke of Sri Lankan Tamils the way the French speak of Quebecois - the same language but different as it had remained isolated, severed from the motherland for many years, and was spoken by a distinct minority, closely protecting its ways in the midst of a vast majority of others. Now, with this growing infusion of Tamil refugees, my city became the epicenter of the Tamil diaspora. ${ }^{12}$ I wanted to understand why this had taken place, seemingly overnight. I

\footnotetext{
${ }^{12}$ Cheran. R, Diaspora Circulation And Transnationalism As Agents For Change In The Post Conflict Zones Of Sri Lanka. Department of Sociology and Centre for Refugee Studies, York University, Toronto 2003.
} 
soon learned that these Tamil migrants, a minority ethnic group of mostly Hindus in Sri Lanka, had fled armed conflict with the Buddhist Sinhalese majority. The first big exodus was after ethnic riots in 1983 , followed by more in the late 1980 s and early 1990 s. For many Tamils who arrived in Toronto during this time, their first home was St. James Town, the largest high-rise complex in Canada, and "one of the most densely populated neighbourhoods anywhere in North America." ${ }^{13}$ It was also just a few blocks from my home.

In these early days, almost all Tamil refugees were young, single men, and for them it was about survival. They worked multiple shifts, lived together in groups to cut costs, and shared beds on a rotating schedule. ${ }^{14}$ Once these young men had jobs, they sent portions of the earnings back home to pay off debts-usually incurred to make the journey to Canada-and to help their families. In her writing for Research on Immigration and Integration in the Metropolis, urban planner and academic Leonie Sandercock wrote of the subsequent settlement process that as "Tamil migration shifts from young men to the formation of families, so too does a tightly-knit neighborhood emerge as small businesses open by and for this community and the area that is now known as 'Little Jaffna' (within St. Jamestown) begins to take shape."15

Soon, in my neighbourhood, Tamil-owned retail businesses flourished in the vicinity and revitalized a depressed area intersected by Parliament and Wellesley

\footnotetext{
${ }^{13}$ St. James Town, website, About the Neighbourhood; Profile http://www.stjamestown.org/about-the-neighbourhood/

${ }^{14}$ Leonie Sandercock, The Quest for an Inclusive City: An Exploration of Sri Lankan Tamil Experience of Integration in Toronto and Vancouver, University of British Columbia [electronic resource] (British Columbia: Metropolis, 2004), 12-13.

${ }^{15}$ Sandercock, Inclusive City, 13-14.
} 
Streets. Since their sizable population required culturally specific goods and services, the entrepreneurs in the community opened grocery and clothing stores, bookshops and libraries, newspapers, radio and television stations, temples, and churches.

It wasn't long before I noticed brown-skinned brothers working in the kitchens of Toronto's bustling restaurant scene. An army of brown-skinned men had arrived: they washed dishes, cleaned tables and cooked behind the scenes. Although they remained invisible beyond the kitchens, their culinary skills were visible on the plates and discriminating palettes of restaurant patrons. They cooked every food imaginable: from risotto to ratatouille, brisket to bolognese, these brothers infiltrated the restaurant industry-but only through the back doors. I noticed they were not on the frontlines as hosts, waiters or bartenders and remained away from direct contact with clientele. I wondered if this was by choice, circumstance or design. I decided to use the conceptual frame of 'Brothers in the Kitchen' as a point of departure for a documentary on the story of the Tamil diaspora in Toronto. I wanted to explore and understand their struggle, displacement, migration, settlement, and agitation, at least by some, for a Tamil Homeland-Tamil Eelam. ${ }^{16}$

\footnotetext{
${ }^{16}$ R. Cheran and Aparne Halpé, On Responsible Distance: An Interview with R, Cheran by Aparne Halpé. University of Toronto Quarterly, Volume 84, Number 4, Fall 2015, pp. 90-108 (Article)

"The whole notion of the Tamil liberation struggle in the eighties was centred on the idea of a separate territory called "Tamil Eelam" for the Tamils, and this was a response to the systematic oppression and marginalization of the Tamils by the Sri Lankan State. This is what we call the national oppression. I think that the conditions that gave rise to the need for a separate state still exist. The condition was the inability and the unwillingness of the Sri Lankan State to reform - transform - itself to accommodate Tamils and Muslims. The demand for the recognition of Tamil as a nation is present in current articulations by the Tamil National Alliance and other Tamil parties, even though they are willing to live under a united Sri Lanka. This has become their discourse. But the contradiction is that the Tamil nation has become a "transnation" because, while they have been fighting for territory, almost a million and a half Tamils have left the country, and the exodus continues."
} 
I began the initial research for this labour-of-love project in hopes of turning it into a conventional documentary film by finding and interviewing individuals about their personal stories, by reading books, newspaper articles, attending Tamil functions, reviewing television and radio reports and through literature and cinema. I succeeded in locating a significant number of people who had arrived as refugees off the coast of Newfoundland on August 11,1986, illegally smuggled on the cargo ship called The Aurigae. ${ }^{17}$ These people had paid thousands of dollars to an unscrupulous German ship captain, Wolfgang Bindel, to run them from Germany to Montreal. Instead, Bindel dumped them unceremoniously into lifeboats somewhere in the North Atlantic.

I also spoke to other Tamils in the community, including leaders, elders, settlement workers and lawyers and members of Tamil agencies, such as the Canadian Tamil Congress, ${ }^{18}$ who provided community supports. I also interviewed local politician, Barbara Hall, who was the city councilor in the St. James Town area at the time.

As I moved through my research, the original story idea started to take shape as a documentary film for television broadcast. I played with various titles including: Strange Cargo, The Aurigae, Hidden Tiger, and Brothers in the Kitchen. I also unsuccessfully pitched an installation on this story to Nuit Blanche, Toronto's annual allnight art festival.

Despite some progress developing the project, I encountered serious problems. For many, the topic was taboo. There was much fear and mistrust in the air. Most

\footnotetext{
17 James Markham, Special to the New York Times, August 17, 1986. http://www.nytimes.com/1986/08/17/world/german-captain-denies-role-in-tamils-journey.html

18 Canadian Tamil Congress http://www.canadiantamilcongress.ca/
} 
subjects were highly reticent to tell their stories on camera. As the war in Sri Lanka was actively raging, people feared for their lives and the safety of lovedones back home. Others were afraid of being deported for entering Canada illegally. Still others feared repercussions from the Tamil Tigers, ${ }^{19}$ a political and military group fighting for Tamil independence, with representatives living and fundraising in both Sri Lanka and Toronto. ${ }^{20}$ Some subjects agreed to do interviews but then denied permission for me to use them afterwards. Others agreed only to audio interviews so their faces would never appear. I even learned that some doubted my genuineness with allegations that I could be a spy working for the Indian army. Nobody seemed to see this project as meriting value or interest, including the broadcasters and the National Film Board of Canada that I pitched it to. After several years and much work, I became discouraged and demoralized. I reached a dead-end. That was fourteen years ago.

At the same time, rapid advances in digital video technology not only shrunk the cost of video cameras, they shrunk the cameras too. Small camcorders such as the Sony PD $150^{21}$ revolutionized the industry, and early adaptors like direct cinema's Albert Maysles proclaimed "such cameras would usher in a new wave of documentary film by granting shooters unprecedented freedom, access, and opportunity."22 Although this

\footnotetext{
19 Amarnath Amarasingam, "Pain Pride, and Politics: Social Movement Activism and the Sri Lankan Diaspora in Canada" University of Georgia Press. (Athens: Georgia, 2015) p1. And “Tamil Tigers," in CBC News online, April 20, 2009 http://www.cbc.ca/news/canada/tamil-tigers-1.783483

20 Ibid

21 Bruce Coykendall, “Sony Dsr-Pd150 Dvcam Camcorder Review” in Videomaker Magazine, May 2002 https://www.videomaker.com/article/c5/8869-sony-dsr-pd150-dvcam-camcorder-review

22 Charles Loxton, "Albert Maysles (1926-2015) Pushed Documentary Filmmaking Forward to the Very End” in Browbeat Magazine Slate's Culture Blog, online March 7, 2015.

http://www.slate.com/blogs/browbeat/2015/03/06/albert maysles dead grey gardens director pushed documentary filmmaking.html

"Maysles even used the Sony PD150 to shoot an entire documentary commissioned for broadcast about Martin Scorsese and his crew on the set of his 2003 film Gangs of New York"
} 
'revolution' leveled the playing field for independent producers like me, we were now expected to deliver projects on miniscule budgets with the same quality and production values of big budget productions. Faced with the economic pressures of sustaining a small independent production company, coupled with the broadcast industry's lack of interest in the 'Tamil Sri Lankan' subject, prospects of moving forward with this production were bleak. With regret, I decided to place the project on the back burner. A dozen years later, I found myself increasingly disheartened by the state of the independent documentary landscape in Canada. If anything, my prospects had shrunk further. Mainstream subject matter seemed to dominate. Fewer resources were available. On the brink of leaving the profession, I seized an extraordinary opportunity to enroll in the Master of Fine Art (MFA) Documentary Media program at Ryerson University and decided to revive Brothers in the Kitchen as my thesis documentary project. I began my research anew but quickly realized that with the passage of time (three decades since the first arrival of the Tamil refugees), the stories had changed and so had I. And there were new stories-those that moved beyond the Sri Lankan trauma into a fresh 21st century start in Canada.

I began to use the MFA as an opportunity to combine my practical experience with producing documentary films with my immersion in theoretical studies about documentary - an exciting and refreshing time for me-and to take risks, free from industry and broadcaster-imposed restrictions. And the academic environment began to change me. I had initially seen documentary as a pure 'from-the-horse's-mouth' kind of storytelling but readings in the MFA program made me question this position. For 
example, filmmaker Malcolm Wyer, in his discussion on meta-documentary, challenged that notion by stating that the "omnipresence" of documentarians like Jean Rouch, in his ethnographic films "demonstrates that cinema verite (a term coined by Rouch) is not a portrait of real life, but a real portrait of life existing within cinema." ${ }^{23}$ Thus the cinema, framed by the camera was already framed by the filmmaker and therefore was mediated. Another opinion advanced by various documentary theorists about the documentarian's intention to frame the subject is shared by Michael Renov, who stated that "issues of selection intrude (which angle, take, camera stock will best serve); the results are indeed mediated, the result of multiple interventions that necessarily come between the cinematic sign (what we see on the screen) and its referent (what existed in the world. ${ }^{24}$ And I began to reflect on how the filmmaker makes choices that influence what the viewer finally sees.

One of my earliest theoretical and practical 'aha!' moments was during the first semester (October 2014) in the documentary production class when I delivered a threeminute silent documentary titled, Pirate, which captured the process of a pumpkin being carved into a Halloween jack-o-lantern. This assignment was just after a screening of Robert J. Flaherty's seminal documentary Nanook of the North. ${ }^{25}$ One of Nanook's most fascinating scenes showed the construction of an igloo from the outside and from the inside. I learned that Flaherty had used a second three-walled igloo to capture all of the

\footnotetext{
${ }^{23}$ Malcolm Wyer, "Meta-Documentary of a Meta-Documentary" in The Brooklyn Rail, July 2009. http://www.brooklynrail.org/2009/07/film/meta-documentary-of-a-meta-documentary

${ }^{24}$ Michael Renov, "Toward a Poetics of Documentary" in Theorizing Documentary, edited by Michael Renov (New York: Routledge, 1993), 26.

${ }^{25}$ Roger Ebert, "Nanook of the North" review in RogerEberg.com, September 25, 2005. http://www.rogerebert.com/reviews/great-movie-nanook-of-the-north-1922
} 
igloo's interior shots. I revealed to the class that I too used a double-a second pumpkin, with one side removed to better access the interior shots for my short film. This sparked much debate about the appropriateness of such a construct, the believability of the documentary image, and the intent of the storyteller. By using a second pumpkin, I intentionally crossed the visual line. Today we know that Flaherty intentionally crossed other lines as well. Through this experiment, I realized that a documentarian can often alter the truth by constructing or manipulating the story-but at what cost? I wondered, how far is too far?

Similarly, later that fall I decided that the camera doesn't lie, people do. In a presentation for my documentary history class, I explored our faith in the camera to register truth. I considered the manipulated photojournalism of Timothy O'Sullivan and Alexander Gardner ${ }^{26}$ during the American Civil War. Years later, it was discovered that these men moved and redressed a dead soldier in order to manipulate the narrative of this war. Similarly, photographer Joe Rosenthal's Pulitzer Prize winning World War II image Raising the Flag on Iwo Jima ${ }^{27}$ was also restaged for the camera in order to more prominently showcase the American flag. In his essay, Ethics, Brian Winston asserts that "the concept of 'fakery' has been so broadly construed that, in its naïveté, it echoes the old error-'the camera cannot lie"28. Winston elaborated that the camera became an invaluable tool to manipulate the message. When I understood that these iconic photos, that we all know so well, were actually staged and/or restaged for the camera in order to

\footnotetext{
${ }^{26}$ Hilary Parkinson, "The true story behind the Gettysburg sharpshooter" in The National Archives, June 20, 2013. https://prologue.blogs.archives.gov/2013/06/20/the-true-story-behind-the-gettysburg-sharpshooter/

${ }^{27}$ Brian Winston, ETHICS, p181, Alan Rosenthal, John Corner Manchester University Press, May 13, 2005.

${ }^{28}$ Winston, ETHICS, p183
} 
manipulate, I became more intrigued about how my own intervention as a filmmaker could allow me to mediate the message. But I wanted to ensure that such manipulations were not at the expense of the truth or compromised ethics.

In the winter semester, I visited a photo exhibit titled DISPATCH: War photographers in print, 1854-2008, at the Ryerson Image Centre. One picture that attracted my attention wasTaliban by Luc Delahaye, a life-sized horizontal photograph of a dead Taliban soldier lying alone in a shallow depression. The hanging picture felt like a casket. "I stood before it silent and pensive, as I have done so many times in front of many other caskets before interment. The difference here is that, this particular viewing will remain forever a viewing - no burial, no song, no fife, no drum.."29

This inspired me to build on my newly acquired skill as an editor, and dig into my more honed skills as a performer, guitarist and poet for my next class assignment. I created a site-specific, performative multimedia presentation to explore Susan Sontag's book Regarding the Pain of Others. I used a life-sized photocopy of the dead Taliban soldier image as part of my performative class presentation. I edited on-camera interviews, radio interviews, images of drone bombings from the Internet, clips from movies, and poetry into a ten-minute audio-video presentation, against which I performed a live musical score on my electric guitar. All the while, the life-sized photocopy of the dead Taliban soldier lay on the long table surrounded by candles I had placed there to create an unnerving installation, a meta-cinematic funeral.

${ }^{29}$ Cyrus Sundar Singh, "Soldat du Fortune", in Filling in the Blanks: Filling in the Blanks: Essays on Art, Media and Culture.Media Writing Fall, 2014, Ryerson University (Toronto: Ryerson University, 2014) 297 
The dead-soldier-on-the-table sparked debate about the appropriateness of certain imagery in documentary, and the intent of the storyteller. I had to leave immediately after my presentation and left the dead-soldier-on-the-table, which caused much uneasiness amongst my cohorts. Someone eventually removed it from the table-without my permission, apparently out of respect for the dead. The performance, the engagement, and subsequent removal of the 'corpse', bore witness to the symbiotic relationship inherent between the story and the audience's will to affect that story. Here, the audience had a visceral reaction to the seemingly abandoned body and a perceived lack of respect for the dead.

Interestingly, in 2003 the original four by eight foot colour photograph of the Taliban was listed for sale at the Ricco-Maresca Gallery in New York for $\$ 15,000 .{ }^{30}$ Why is it considered expensive art on the gallery wall but disrespectful on the table of the Ryerson grad lab? To me, this experiment helped tease out the idea of constructing mood and set, audience participation, the importance of site, and the impact of live performance. My trajectory towards 'performing the documentary' was taking shape.

Around this time, I met Princy and Asanka, a recently married, young Torontobased, Sri Lankan couple, who became potential subjects for my documentary. Princy is a Christian Tamil of Sri Lankan birth who fled her homeland with her mother and brother and found refuge in Canada. Asanka, a Sinhala Buddhist, was also born in Sri Lanka and had just arrived in Toronto when I met him in fall 2014. The couple disclosed to me

\footnotetext{
${ }^{30}$ Bill Sullivan, "The Real Thing: Photographer Luc Delahaye", Sullivan interview with Delahaye in Artnet, October 4, 2003. http://www.artnet.com/magazine/features/sullivan/sullivan4-10-03.asp, and

Liam Kennedy and Caitlin Patrick, The Violence of the Image: Photography and International Conflict, edited by

Liam Kennedy and Caitlin Patrick, London: Tauris 2014. p242
} 
that they had been secretly married for four years and that neither side of their respective families knew of their relationship nor would their families approve of such a cross-cultural union. After all, the Tamils and Sinhala were mortal enemies in the civil war. I found myself face to face with the proverbial 'star-crossed lovers'-a Sri Lankan Romeo and Juliet. I instantly wanted to include them in my documentary but they didn't fit the easy story of good guys and bad guys. Their situation was more complex which forced me to reconsider the Sri Lankan conflict, and my telling of it, in more layered and nuanced terms. I felt I couldn't include them in a conventional, linear documentary framework. And what if they had children born here? Where would their place be in the story? To me, this mixed couple represented 'hope' for the future, and such hope pushed me to develop a more complex and nuanced approach to what was clearly not a black and white story. How could I do that?

I wondered how I might capitalize on emerging technologies to do so. The advent of new digital technologies had vastly reshaped the conventional landscape of content production, delivery and consumption. Today, we can use our mobile phones to disseminate narratives that could result in socio-political sea changes. That was not the case in Sri Lanka of the 1980s. However, it was the case of the Arab Spring. In a University of Washington article about a study quantifying social media's role in the Arab Spring, writer Catherine O'Donnell posits that, "[i]n the $21^{\text {st }}$ century, the revolution may not be televised-but it likely will be tweeted, blogged, texted and organized on 
Facebook..." ${ }^{\text {31 }}$ York University Cinema Studies Professor Janine Marchessault eloquently captured the milieu:

Twenty years ago, communication theorists predicted the media were converging into one and that all information would be transmitted through a singular medium - a concern echoing the cultural theorists of the early part of the century. Yet at the beginning of the twenty-first century, we can see that no one medium will dominate the mediascape. The stories consumed in the industrialized democracies of the world are received through a multiplicity of hybrid and networked screens, creating a fragmented reception that increasingly characterizes our waking hours. ${ }^{32}$

I was intrigued by this observation and wondered how it could inform my own work. Furthermore, I opened myself up to the influences of a diverse range of seminal documentary films shown in class such as Paper Wheat, Chronique d'un été, Shoah, Episode of the Sea, My Winnipeg, Sherman's March, and The Arbor. From Paper Wheat's innovative documentation of a theatrical play to The Arbor's use of verbatim theatre, these films reflected back on performance, and pushed the boundaries of the conventional documentary form.

I also became stimulated by the large-scale multimedia drama and theatrical work of Robert Lepage, and was especially inspired by the RSVP Cycles ${ }^{33}$ methodology developed by his mentors, Lawrence and Anna Halprin. These Cycles offer a method of producing performed work where one can use physical resources, community resources, score (or script), and performers in any combination to achieve a creative vision. These are the building blocks of what is needed to create a democratic creative

\footnotetext{
${ }^{31}$ Catherine O'Donnell, "New study quantifies use of social media in Arab Spring", in UWTODAY, University of Washington, September 12, 2011.

http://www.washington.edu/news/2011/09/12/new-study-quantifies-use-of-social-media-in-arab-spring/

32 Renov, "Poetics of Documentary", p26.

${ }^{33}$ Lawrence Halprin, Creative Processes in the Human Environment (New York: Braziller, Inc.. 1969)
} 
work. It also allows for improvisation. According to freelance dramaturge Gyllian Raby who, "learned it at Théâtre Repère from Robert Lepage and Marie Brassard", the RSVP Cycles are "a compass of interconnective creative mindsets rather than a prescriptive "how-to" methodology." ${ }^{34}$ In terms of producing, it is about "using resources versus themes as starting points." ${ }^{35}$

RSVP stands for: Resources: the human and material resources available; Score: ways to generate the dramatic content; Valuaction: selecting and analyzing the material; and Performance: presentation and audience feedback. ${ }^{36}$ In a printed interview with playwright and filmmaker Alice McAlpine, Lepage revealed, "I've always intuitively used the [RSVP] method in a sense that I was already working in that way without knowing that it could actually be a cycle, or a way of working, or a method..37 Lepage's revelation was striking to me as it validated my own intuitive methods. I too unknowingly used such an approach to produce work within my own practice. My discovery of this methodology helped me envision the next phase of my work.

Likewise, Grounded Theory Methodology (GTM) helped me to understand how to find commonality in disparate elements and to connect them within a creative framework. Created by sociologists, Barney Glaser and Anselm Strauss ${ }^{38}$, the GTM is a set of research strategies related to "social and scientific inquiry." It "avoids making

\footnotetext{
${ }^{34}$ Gyllian Raby, "Improvisation and Devising: The Circle of Expectation, the Invisible Hand, and RSVP," in Canadian Theatre Review, vol 143, Summer 2010 pp 94-97 (Article) Toronto: University of Toronto Press.

${ }^{35}$ Ibid

${ }^{36}$ Halprin, Creative Processes, p2. The "term "valuaction" is one coined to suggest the action-oriented as well as the decision-oriented aspects of $\mathrm{V}$ in the cycle."

${ }^{37}$ Alison McAlpine. "Robert Lepage in conversation with Alison McAlpine," In Contact With The Gods? edited by Maria M. Delgado and Paul Heritage (Manchester: Manchester University Press 1996), 134

${ }_{38}$ Barney Glaser and Anselm Strauss, The Discovery of Grounded Theory: strategies for qualitative research, (New York: Aldine Pub. Co., 1967)
} 
assumptions and instead adopts a more neutral view of human action in a social context." ${ }^{39}$ In documentary filmmaking, one could say GTM allows the documentary to follow the story versus the story following the documentary. This means the filmmaker should use the unexpected and unscripted (like the star-crossed lovers Princy and Asanka), and be open to its contribution to the creative result, even when it initially may seem inconsequential. To my delight, I realized that I had been intuitively using the kind of methods outlined in RSVP and GTM in my work without ever knowing of their existence. This gave me the confidence that my process could achieve results akin to people like Lepage. This was esteem-building and liberating to me.

On top of RSVP and GTM, viewing the performative documentary, The Arbor ${ }^{40}$, further inspired me. This film, directed by Clio Barnard, uses fact, fiction, metacinema and verbatim theatre to tell the real story of playwright Andrea Dunbar's short and tragic life. Performers lip-synched verbatim testimony and excerpts from Dunbar's original autobiographical play in this revolutionary work that also takes the audience back thirty years. This combination of documentary, theatrical and cinematic conventions and unexpected innovation toyed with the viewer's expectations of storytelling. By taking an autobiographical play and retelling it as a film performed by a mix of actors and real people sometimes playing themselves, and sometimes playing others, the film challenged the audience's idea of what is real and unreal, what is truth and what is fabricated. In the end, what is remarkable is that it did not matter to me, for the story

\footnotetext{
${ }^{39}$ Odis E. Simmons, "Some Professional and Personal Notes on Research Methods, Systems Theory, and Grounded Action" in World Futures Vol. 62 , Iss. 7, 2006

40 Peter Bradshaw, “The Arbor- review." In The Guardian. October 21, 2010

https://www.theguardian.com/film/2010/oct/21/the-arbor-film-review
} 
remained strong and compelling and the audience was provoked moved and engaged. The end justified the means.

The Arbor helped me with problem solving and I had serious, unresolved problems with my Tamil documentary. As time had passed, I had lost touch with some of my original subjects. I had footage of people shot many years ago whose remarkable testimonies could no longer be used because they now feared exposure through my project. Furthermore, I had audio recordings - not video-in cases where reticent subjects did not want to be seen on camera in the first place. I didn't know how to make my documentary under these restrictions. But The Arbor helped me see that these needn't be restrictions. Instead, it gave me license to be creative. I too could use the verbatim transcripts of my subjects as part of a script performed by others, even actors. I need not be limited by passage of time or having lost track of certain interviewees. The limitations or opportunities were as I chose to shape them. These were my problems to solve creatively: my art to make.

It was a confluence of these experiences that guided my next steps; the experiment I did with the second pumpkin allowed for creative visual manipulation without compromising truth; the experiment with the Taliban image told me that performance involving a live audience and the use of place/space can escalate and elevate the impact of art, and The Arbor demonstrated how actors using verbatim transcripts is perfectly acceptable. There are many ways for an artist to tell a compelling and legitimate story. These revelations afforded me the creative license to revise my thesis project from a conventional documentary film to a performative live-documentary. 
This gave me permission to do something that I was already contemplating-having others speak the words in select testimonies I had captured to date. This meant I needed to think about performance, audience, and site. This meant I might need to develop a script. But how could I do this?

I found part of the answer through verbatim theatre. I was not aware of this tradition or the scholarship around it. Instead, as described above, I intuitively realized that using verbatim testimony was a dramatic, truthful and authentic solution to my problems of lost and reluctant subjects. I learned after-the-fact that there was scholarship to support my intuition.

As noted by dramatist Derek Paget, documentary and verbatim theatre share "a connection through the twin spaces of the recording of the words and their reproduction in performance, ${ }^{41}$ a device that is consistently used in documentary filmmaking represented by on-camera interviews. They also share in the performative relationship where "the audience is partly 'cast' as interviewer, and this always offers the possibility of enhancing the directness of contact with the speaking actor." ${ }^{\prime 2}$ Moreover, the speaker (actor/subject) and the listener (audience) need each other to create a meaningful interactive experience together. This performative interaction of verbatim theatre was further observed by actor and dramatist Robin Soan:

"[m]ost performances have a geographical as well as an emotional and psychological shape: [...] approximately ninety per cent of the actor's relationships are with the other actors on stage, and ten per cent are with the audience, in the form of asides. In verbatim theatre, the ratio is reversed: ten per cent of the time you interact with your fellow actors on

\footnotetext{
${ }^{41}$ Derek Paget, Acts of Commitment: Activist Arts, the Rehearsed Reading, and Documentary Theatre, Cambridge University Press, May 2010, p188

${ }^{42}$ Ibid
} 
stage, but ninety per cent of the time your attention is directed towards the audience." ${ }^{.43}$

One night, I had a breakthrough that unknowingly related to verbatim theatre and my documentary. I was working late to finish the final presentation for my thesis production course that was due the next day. As was the convention, I was in the process of editing a short video trailer to show a summary of my project's development to date. I hated the trailer. It did not capture the multilayered and important human story; it was mediocre and shallow. It did not excite or engage nor did it capture my vision for the documentary. It was two in the morning and the presentation was due at noon. This also affected me physiologically and I felt depressed. It was then that I had an epiphany. I realized the inherent drama in the verbatim words of my subjects that I had already interviewed and captured. I pulled out my transcripts, scrapped the video trailer and reenvisioned the documentary through the pages of a script. While I was writing that script, an enormous creative-weight lifted off my shoulders. Moreover, the script allowed me to see Brothers in the Kitchen in a new setting. In fact, I literarily saw the "brothers" inside a real kitchen, within a restaurant. I envisioned Brothers in the Kitchen in a new light, no longer constrained by the limits of traditional documentary form. Rather than a conventional linear documentary structure, I decided to create a container (a physical, metaphorical and philosophical space) into which I would house and explore the various parts of the story.

\footnotetext{
${ }^{43}$ Robin Soans, in Verbatim, verbatim: contemporary documentary theatre. Edited by Will Hammond \& Dan Steward. London: Oberon, 2008. p 21
} 
A container is a tool with numerous uses and meanings. In its utilitarian state, as a noun, a container is used to hold, transport and protect food, goods, ashes, or memories, etc. In a political state, a container may be used to hold, transport and secure rabid animals, prisoners, and refugees. A 'container' also keeps things orderly during storage and transport. As a verb 'contain' is used to keep something fenced in, corralled, behind a prison wall, inside a razor wire fence around a refugee camp. This metaphor became even more meaningful to me because the 'vessel' that brought the one hundred and fifty-five Tamil refugees to Canada was a cargo ship-a container. A container can also be used to cook food and much like a stewpot, the performance 'site' could become a container in which multiple connected and/or seemingly unconnected stories, ideas, and related materials simmer and sizzle to create the documentary-stew. I would use a real restaurant as my site-specific container and serve up food and stories. This restaurant would become the Happy Fish Café ${ }^{44}$-a venue where the brothers and sisters in the kitchen could play themselves as documentary subjects supplemented by actors, musicians, dancers, and poets.

That night I further developed the notion of the container and transformed my outline/treatment into a traditional script-a set of instructions, actions, and verbatim text in the telling of the story. This script encompassed all the conventional tools of documentary filmmaking: story; subject(s); setting; narration; montage; maps; archival materials; interviews; reenactment; framing; lighting; musical score; sound design; etc.

\footnotetext{
${ }^{44}$ Throughout the mid-1990s, I produced numerous live events under the banner Happy Fish Café, at different venues across Toronto. I brought together a diverse range of artists from storytellers, musicians, poets, singers, and thinkers and put them all into that Café. Food was also an integral part of the Happy Fish Café experience. In many ways the Café was an early prototype of a creative 'container'.
} 
In addition, it also contained some conventions of theatre, specifically the Greek

Chorus. Whilst the site or container would hold the unfolding stories, the script allowed me the freedom to map out the documentary. I now understood the power of the script.

I pulled an all-nighter to draft my script and used verbatim transcripts of past and present interviews with real subjects, archival information, transcripts of newspaper articles and television broadcasts to do so. I constructed a trilogy: the uprising, exodus and survival of the Tamil minority. Euphoric, I walked into my class at noon the next day armed with six copies of a draft script and, with the help of five volunteers as readers, we performed an early iteration of the Brothers in the Kitchen. The combination of script and the role of audience volunteers enabled me to see and hear the documentary as a live performance. This got me further thinking about how to use audience participation and my own role as a performer and how that may be incorporated into the work.

Soon, I got to test drive my ideas using another project. The literal and figurative halfway point towards Brothers in the Kitchen was on May 21, 2015, when I presented Africville in Black and White-a twenty-minute site-specific live-documentary-inside the main sanctuary of a church located beside Ryerson University. The piece was built upon my first critical essay of the same title and was presented at an international conference $^{45}$ co-hosted by Trent and Ryerson Universities. Ryerson University Professor Blake Fitzpatrick outlined what happened:

In May 2015, I hosted an International conference at Ryerson titled Critical Topography. The conference addressed issues related to the

\footnotetext{
${ }^{45}$ Critical Topography Conference, May 20-22, 2015

https://www.trentu.ca/culturalstudiesphd/criticaltopography.php
} 
politics of place and brought renowned researchers from Europe, United States and Canada to Ryerson. As one of the participating graduate students, Cyrus brought the conference delegates to the First Lutheran Church on Bond Street and delivered a lecture/performance on race relations in the Halifax neighbourhood of Africville. This was not the reading of an academic paper as one might expect. Instead, Cyrus delivered a spoken poem and live musical performance, with audio-visual interpretation in a place of worship and spirituality that spoke of a racial injustice in Canada. ${ }^{46}$

In Africville in Black and White, I sought to shine a light on a neglected case of racism in Canada:

Located just north of the city of Halifax, Africville was home to 400 African-Canadians for over 60 years, who were evicted by the city in the 1960s. The entire site was bulldozed, along with the Seaview African United Baptist Church, which was called "the beating heart of Africville", as it was the centre of the village. The land of Africville was eventually turned into ramps for the A. Murray MacKay Bridge, the Fairview Container Terminal, and private housing. The village's centre turned into Seaview Park - a dog park. ${ }^{47}$

Africville in Black and White was a site-specific ephemeral documentary

performed inside a church with an audience. The church became a "container", (a physical, metaphorical and philosophical space), in which the various parts of the Africville story in conjunction with the audience unfolded. The triumvirate of story, performance, and audience was used to create an interactive and immersive documentary experience and incorporated various traditional and contemporary elements such as: oral storytelling, poetry, musical score, and archival materials-all

\footnotetext{
${ }^{46}$ Blake Fitzpatrick, Letter of Support investiture for the Alan Shepard EDI Award February 2015.

${ }^{47}$ Narissa Van Cooten, "Africville in Black and White To Premiere At b current's rock.paper.sistahz Festival", Pride Magazine, May 2, 2016

http://pridenews.ca/2016/05/02/africville-black-white-premiere-b-currents-rock-paper-sistahz-festival/
} 
performed live. In addition to me as the main narrator and composer/guitarist, I was joined by hymn singer Shelley Hamilton, an Africville descendent. The energy of the performance was shared between all three "players": the narrator (the outsider), the singer (the insider), and the audience (the Africville diaspora). As with verbatim-theatre, all lines were pulled from transcriptions and the verbatim script was printed in a program that doubled as a liturgy that was followed and recited aloud by the audience (congregants). For the duration of the performance, the audience stood-in as the subjects of the story: the displaced Africville community.

I chose to use audio and live performance in a specific site to create a simple low-tech, low-budget production. The intimacy and interactivity between the audience and performer allowed for the Africville story to become more of a collective experience. This small-scale performance became a working template for what later became a more fully involved, far more complex, tech-heavy production of Brothers in the Kitchen-with significant cast, crew, cooks and cameras. And this test case was a success. According to Fitzpatrick:

Inspirational, and profoundly moving, the combination of performance, message and setting combined to challenge all participants to imagine a more inclusive Canada. Many in attendance, including the International experts who participated told me that this was the highlight of the conference. $^{48}$

This project's success emboldened me to infuse similar techniques into my thesis project. It is as a result of Africville in Black and White that I confirmed my hypothesis that performance before a live audience enhances and heightens experience for both

\footnotetext{
${ }^{48}$ Ibid
} 
the audience and the artist due to the uncertainty and resulting spontaneous deviations that cannot be predicted and would never result at the traditional screening of a finished film. I started to understand that a big part of why I was exploring performative documentary was not just for the experience of the audience, but also for my experience as an artist. I get an enormous kick out of not knowing where a performance will go, even with a script. It is far more thrilling to actively participate in the presentation of the art with the audience rather than passively awaiting their reaction to a finished film. This way my work isn't finished after the edit; my work continues and is alive each time the work is presented. I now realize how similar this is to the point of view of Robert Lepage who said:

The writing starts when you perform and it's a difficult thing to comprehend for a lot of people in this field of work because we are used to the traditional hierarchy of the author, and the script being put in the hands of the director who reshapes it, or re-moulds it, or tries to squeeze or apply his concepts onto it... There can actually be a sportive and active phenomenon happening on stage. If you achieve that, it is very theatrical. ${ }^{49}$

It is important to note here, that while I was developing both Africville in Black in White and Brothers in the Kitchen, Europe was facing a crisis. "More than a million migrants and refugees [primarily from Syria] crossed into Europe in 2015, sparking a crisis as countries struggled to cope with the influx, and creating division in the EU over how best to deal with resettling people. ${ }^{" 50}$ Coincidentally, on December 10, 2015, just before winter break, I presented an interim proof-of-concept for my Brothers in the

\footnotetext{
49 McAlpine. "Robert Lepage ", 134-135.

50 Migrant crisis: Migration to Europe explained in seven charts" in BBC News Online, March 4, 2016 http:/www.bbc.com/news/world-europe-34131911 downloaded August 28, 2016
} 
Kitchen thesis to a classroom filled with Ryerson faculty and MFA cohorts. That day proved auspicious for my project. It was the same day that one hundred and fifty Syrian refugees arrived at Toronto's Pearson International airport, and our newly elected Prime Minister Justin Trudeau greeted them in person.

Although over a generation apart, the arrival of the Syrian refugees in Canada on December 10, 2015 helped validate the arrival of the Tamil refugees thirty years earlier. Ironically, the unfortunate and horrific life and death struggle of one community of refugees fleeing a brutal civil war allowed the narrative of another community of refugees who fled similar circumstances to finally be heard. Almost instantly the Tamil Sri Lankan story was listened to and supported from within the industry, and from within the academy. The valuable outcome from this synchronicity was the boost to my selfconfidence, which in turn strengthened my resolve to keep moving forward. I was in the right time and the right place both creatively and academically to capitalize on this.

I am convinced that without this migrant crisis in Europe and the Middle East, relatively few would have been interested in my tale of Tamil refugees. But the parallels were too strong. This, and also the fact that the protracted war in Sri Lanka had ended in May 2009 and enough time had passed since the events of 1986 that people were finally ready to address this topic.

On December $29^{\text {th }}$, shortly after our Prime Minister welcomed the Syrian refugees, I pitched Brothers in the Kitchen as a live, site-specific performative documentary to Shane Smith, Director of Programming at Hot Docs Canadian International Documentary Festival and received the official 'greenlight' in mid-February. 
Over the subsequent four months, I engaged in an intense period of pre-production so that after 14 years, Brothers in the Kitchen was finally born. On May 4, 2016, it had its world premiere at the festival in Toronto.

The story recounted the uprising, exodus and survival of Tamil Sri Lankans who fled a brutal civil war and sought refuge in Canada. The ethnic conflict, between the Buddhist Sinhala majority and the Hindu Tamil minority, sparked a mass exodus following the deadly riots known as Black July in 1983. Subsequently, over time, a staggering number of Tamils found asylum in Canada-the largest Sri Lankan Tamil diaspora in the world. ${ }^{51}$ Eventually, a significant number of them began work as cooks and dishwashers in the kitchens of many Canadian restaurants-hence the title of the documentary, Brothers in the Kitchen. ${ }^{52}$

The production was a site-specific live-documentary, performed inside a restaurant in the presence of the storytellers and the audience, along with a number of supporting cast and crew all vested in 'performing the documentary'. Although this live documentary performance took place inside a conceptual space called the Happy Fish Café, the physical site was the Centre for Social Innovation (CSI) Annex Café ${ }^{53}$ located in downtown Toronto-one block south of the festival's flagship theatre, the Bloor Hot Docs Cinema. ${ }^{54}$

\footnotetext{
${ }^{51}$ Ibid

52 The title Brothers in the Kitchen is a reference to "brothers" who looked like me-brown-skinned and of Indian/Sri Lankan Tamil origin. The title is also a point of reference for a larger audience of non-Tamils who are able to connect easily to the story because they know of or remembered a brown-skinned man/men who they have seen or know working in the kitchens of their favourite restaurant(s). This connection is key in how receptive an audience is in listening to and engaging with a narrative. The reference makes familiar the people behind the story who may otherwise remain the "other"-distant and unattached to the larger Canadian community. Please note that although the title 'Brother' is masculine, I am using it to include all genders, castes, class, and communities.

${ }^{53}$ CSI (Centre for Social Innovation) www.socialinnovation.ca

${ }^{54}$ www.hotdocscinema.ca
} 
The sold-out premiere began with a scripted performative introduction by the festival's Director of Programming, Shane Smith:

Welcome everyone. If you thought you were coming to see a movie tonight, you are in for a delicious surprise. Tonight you will experience something innovative and genre-bending created by Director, Cyrus Sundar Singh. This means you are part of a one-night only, live documentary, performed right here with subjects, experts, narrators, musicians, cooks, and food. ${ }^{55}$

He then adlibbed, "after all you're part of history in the making and you can't make history without dropping a few samosas, ${ }^{, 56}$ which garnered much laughter from the audience and set the informal and interactive tone for this unique, ephemeral livedocumentary experience-a "first" for Hot Docs, for Ryerson University, and for this author/artist.

On that night, thirteen subjects of the documentary, ranging from a septuagenarian to vicenarians, amateurs to professionals, authors and politicians, told their stories live and in the flesh to an audience seated within the same space. With few traditional filters to mediate-such as film, editing, the two-dimensionality of a movie screen, time passage - what was left was a direct, face-to-face relationship between the storytellers and their audience. In the subsequent review of the documentary, writer Corey Mintz described the construct:

As in any documentary, [Sundar] Singh interviewed dozens of subjects, then edited those down to essential pieces that, stitched together, form a clear narrative. But instead of splicing footage he had each interview

\footnotetext{
${ }^{55}$ Appendix A: Cyrus Sundar Singh, Brothers in the Kitchen, Final Script, May 4, 2016, p2

${ }^{56}$ Cyrus Sundar Singh, Brothers in the Kitchen, Documentary Performance May 4, 2016.
} 
subject recount their story live as part of an interactive, multimedia tapestry." 57

From the opening percussive invocation that welcomed the dancers, through the painful first-person accounts to the closing recital of the redemptive Happy Fish poem, ${ }^{58}$ the live-documentary unfolded in real-time. NOW Magazine's film critic Radheyan Simonpillai described it in this way:

At the intimate and interactive gathering, speakers shared traumatic memories, with support from video installations, a live band and dancers whose fluid Bharatanatyam movements channelled the show's poetry, and on occasion, horror. A few technical glitches during the experimental production were welcomed as part of the collaborative process, and the audience was sometimes called on to read archival newspaper clippings aloud. [...] The sheer breadth and depth of the show was astounding. It offered an immersive history on Tamil migration, the memories, music and art all informing a search for what the Tamil-Canadian identity has become, or is becoming. ${ }^{59}$

The site was sparsely decorated with an intimate and cozy feel and a range of seating options. A number of vintage lifejackets and circular life preservers populated the site to evoke the cargo ship, The Aurigae. Off to one side was an open kitchen with an attached beer/wine bar. The kitchen was abuzz with activity. Two female cooks busily prepped dishes and a small camera crew captured the cooking activity, which was simultaneously broadcast on two large TV monitors. On an elevated stage on the far end of the café, a musical trio performed the live score. Their South Asian instrumentation evoked Sri Lanka. On arrival, each audience member was directed to

\footnotetext{
${ }^{57}$ Corey Mintz, "What it's like to be a Tamil refugee in a Toronto kitchen," in TVO's Current Values/Shared Values, published May 12, 2016. http://tvo.org/article/current-affairs/shared-values/what-its-like-to-be-a-tamil-refugee-in-a-toronto-kitchen

${ }_{58}^{58}$ Appendix A: Script p30-31

${ }^{59}$ Radheyan Simonpillai, "Brothers In The Kitchen Serves Up Moving Stories At Hot Docs: Interactive Hot Docs Festival show puts the Tamil immigrant issues on the menu" in NOW MAGAZINE, May 62016.

https://nowtoronto.com/movies/hot-docs-2016/brothers-in-the-kitchen/
} 
pick up a small silver-coloured square box from the bar. Each box contained an edible trilogy - three specific vegetarian snacks: a triangular samosa, ${ }^{60}$ a circular vadai ${ }^{61}$ (doughnut-shaped, like a life preserver), and a spherical sweet ladoo ${ }^{62}$ As the audience found their seats and opened their 'containers' filled with these snacks, an air of excitement and anticipation for the unexpected filled the café; a shared sense of 'bearing witness to' and 'being a part of' something new was palpable. "I felt like I was bearing witness to the grief in a medium of entertainment that was truly unique" said Shirley Roberts ${ }^{63}$ who attended the premiere.

The production also included actors, singers, dancers, a choreographer, and a director, underpinned by a thirty-two-page script (Appendix A). Present within this "tapestry" were two eighty-inch television monitors that, from time to time, came alive with images of: archival footage, title sequence, act breaks, poetry, supers and/or video introductions to specific subjects, interviews via Skype ${ }^{64}$, and Google Earth ${ }^{65}$ maps to help situate the odyssey geographically. Moreover, these television monitors were used to broadcast scenes from Slice $n$ Dice ${ }^{66}$, a real cooking show that was contained within the documentary. Placed between acts two and three, this meta-component was filmed

\footnotetext{
${ }^{60}$ Samosa a triangular wheat-based fried or baked dish with a savoury filling, such as spiced potatoes, onions, lentils or minced meat <http://qz.com/335836/a-short-history-of-the-samosa/>

${ }^{61}$ Vadai is a south Indian fried savoury originating mainly from Tamil Nadu and Karnataka, traditionally prepared during festivals and weddings. This lentil-based item is often served along with breakfast items like idli, pongal etc or even good with any scrumptious meal. >http://www.spiceindiaonline.com/medhu_vadai/>

${ }^{62}$ Ladoo is a sweet sugary ball made from deep fried pearls of Basan flour (Chick Pea). $\mathrm{http} / /$ indianexpress.com/article/lifestyle/food-wine/food-story-the-journey-of-ladoo-from-a-medicine-to-the-muchloved-indian-sweet/

${ }^{63}$ Shirley Roberts: Executive Director, Interim, Parkdale Community Health Centre, Toronto.

${ }^{64} \mathrm{SKYPE}$ is a branded video and audio conferencing protocol, https://www.skype.com/en/

${ }^{65} \mathrm{https}: / / \mathrm{www}$.google.com/earth/

${ }^{66}$ Slice $n$ Dice is a six-part cooking show produced and directed by Cyrus Sundar Singh that is broadcast on BellMedia's FibeTV1 (2015). The show is hosted by Sarah Elton. http://tv1.bell.ca/fibetv1/shows/slice n dice.html
} 
in real time and concurrently broadcast live to the audience via the television monitors.

For the duration of the live broadcast, the same documentary audience thus became a television studio audience of a reality cooking show. This cooking activity infused the site with the fragrant scent of spices thus engaging the audience's olfactory systems as well. Throughout this metacinema, ${ }^{67}$ a small crew of cinematographers and technicians busily documented the documentary with lights, camera, and sound. I played the role of a director on and off camera. This was not the live filming of a documentary. This proved difficult for some to grasp as not only did people ask when the film would be shown, some of the interviewees themselves commented as follows on twitter

At the filming of \#Brothersinthekitchen, a live documentary about the Tamil experience looking forward to it !

\footnotetext{
${ }^{67}$ Metacinema "is a device used to self-consciously and systematically draw attention to a work's status as an artifact." http://uwm-metacinema.blogspot.ca/2015/06/welcome-to-homebase-for-film-203380.html
} 
Bob Rae doing his bit at the live filming of the doc Brothers in the Kitchen \#bitk2016 \#HotDocs16 \#tamil
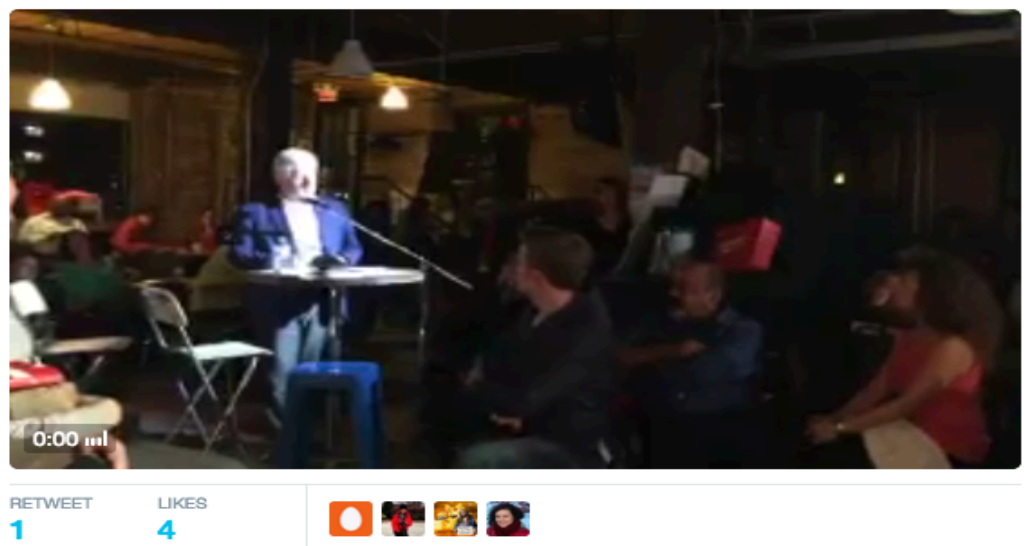

6:43 PM - 4 May 2016

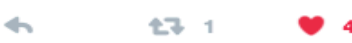

Their belief in the camera's power to document also induced their performances. This is part of why I chose to have cameras and crew present throughout the performance. Presented as chapters of a trilogy-uprising, exodus, and survival-nested within a singular frame, the feature-length documentary carried the narrative across a thirty-year span.

From the opening slate to the closing credits, the live-documentary unfolded as I had envisioned it, with only a few "dropped samosas" here and there. One such example happened towards the end of the survival chapter (Script p27), where British Journalist Francis Harrison read a short passage from her book Still Counting the Dead in a pre-taped Skype interview. In it Harrison captured the horror and brutality faced by the Tamils caught between Tamil Tigers rebel forces and the Sri Lankan Army on the "final offensive" on May 18, 2009. Just as the interview was to be broadcast the technology failed and the segment did not play. I immediately stepped in as the director, 
and using my copy of the script, read the verbatim transcript that I had inserted based on the pre-interview-a meta-moment, where I too became a performer.

The script that framed the story was a key element of Brothers in the Kitchen. It is important to note, however, that the script was not shared with the subjects. Rather I pre-interviewed them on camera and used their verbatim testimonies as a placeholder in the script for my own timing and planning. The script was only used by me and my professional cast and crew. It became a valuable tool, including to remedy the Frances Harrison situation above. Moreover, the process of writing twenty-eight drafts of the script was akin to the editing process of a conventional documentary film. Even with the script and my instructions to the subjects, I could not control how or what they would end up saying, or how long they would take to do so. This resulted in a longer running time than planned.

In the script, I chose to conflate the role of the male cook and narrator into one character called Brother, played by Dora Award-winning actor Anand Rajaram. Brother became the symbolic 'stand in' for the many brothers in the kitchen who were all busily "working shifts in restaurants, cooking everything under the sun: French, Italian and Greek; Pubs, Clubs and Subs; Battered, Blackened and Barbequed."68

At times, Anand also played the role of 'Anonymous,' a real person who provided his personal testimony of his experiences of fleeing Sri Lanka, his passage on the cargo ship, The Aurigae, and his time working in the kitchens of many Toronto restaurants. However, Anonymous did not want to be identified within my documentary:

\footnotetext{
${ }^{68}$ Sundar Singh, "Brothers," p5
} 
Although it has been thirty years since we arrived, I still feel ashamed. If we had arrived by airplane we would feel better. In the early days, the white people would shame us for arriving on a boat. They called us "boatpeople" and used it as a demeaning and subjugating term. I worked in the kitchens as a prep cook and got into many arguments with the bosses about the condition of our arrival. I tried to tell them the story but they did not want to hear it. They accused us of being so poor that we were opportunists who jumped the queue for a better life. We did not want to leave -- we had to leave--or die! ${ }^{69}$

Because Anonymous would not appear, I placed Anand behind a six-foot screen (an opaque white sari) and backlit him in silhouette like a shadow puppet. Anand performed the verbatim words of this absent subject. 'Anonymous' wasn't the only subject who did not want to appear in front of an audience, or unavailable that night, and some 'Brothers in the Kitchen' could not take time off work. Others I had lost touch with over time as described above.

In the absence of actual 'brothers' to populate the kitchen, two veteran Tamil prep-cooks Sasi and Suseela ${ }^{70}$ were employed as 'Sisters' in the kitchen for the documentary. In addition, during the embedded cooking show, Slice ' $n$ ' Dice, the 'Sisters' demonstrated how to cook one of the snack items contained in the boxes that were distributed to the audience at the beginning of the documentary. The 'Sisters' also cooked other items including a sweet vermicelli dessert called Payasam that was served to the audience at the end of the documentary. Sasi and Suseela are also former refugees who fled Sri Lanka after the uprising, and their presence as cooks in the live-documentary also made them a meta part of the story.

\footnotetext{
${ }^{69}$ Anonymous, subject (interviewed by Sundar Singh in Brothers, Script 2016. p25-26

${ }^{70}$ Sasi and Suseela are real prep-cooks who work at Daniel et Daniel catering in Toronto: www.danieletdaniel.ca/
} 
As a participatory element, I invited audience volunteers to play the roles of former Prime Minister Brian Mulroney and fisherman Gus Dalton, both of whom were unavailable for the live-doc but who played important roles in the real story. In 1986, amidst the growing backlash against the Tamil "boatpeople", Mulroney stood in Parliament and stated: "Canada was built by immigrants and refugees, and those who arrive in lifeboats off our shores are not going to be turned away."71 Captain Gus Dalton, a Newfoundland fisherman, was fishing for cod, hake and haddock in the North Atlantic, when on August, 11, 1986 he spotted something through the fog. On closer inspection he noticed two lifeboats filled to the brim, overcrowded with people. He immediately released his entire catch for the day and helped the refugees. Dalton's selfless humanitarian action saved all one hundred and fifty-five castaways. The "wild card" of using volunteers from the audience allowed for playful moments and some levity within particularly dark sections of the story. Moreover, this offered another opportunity for the audience to not only be invested in the telling of this story but also to become part of the story.

I also employed the device of a Greek Chorus ${ }^{72}-$ a theatrical convention whereby a group of characters in a collective voice comment on the dramatic action. Their role "allows the audience to perceive the chorus as both character and performer, and in a moment of metatheatrical distancing, to simultaneously acknowledge this dual identity." ${ }^{73}$ A similar theatrical convention exists in Tamil street theatre in Tamil Nadu in

\footnotetext{
${ }^{71}$ Joe O’Donnell, "Show compassion for Tamil refugees Mulroney urges" in Toronto Star (18 August 1986), (ProQuest—Canadian Newsstand).

${ }_{72}$ Alysse Rich, "Reconfiguring the Chorus: Adaptations of the Greek Tragic Chorus since World War II." PhD diss., University of Toronto, 2012. ch1 p30

${ }^{73}$ Rich, The Chorus, ch2 p89
} 
South India and in Northern Sri Lanka. That tradition includes the character,

Kattiyakkaran. ${ }^{74}$ This name is a composite Tamil word, Katti: to tie, and Karan: man. So, a Kattiyak-karan is he who ties it all together - the one who weaves together a story's disparate threads so it all makes sense.

This character is allowed to break the conceptual fourth wall, address the audience directly, offer opinions and elicit commentary-like a Greek Chorus. However, I flipped the male gender of the Kattiyakkaran with a female trio and coined the gender specific Tamil-English moniker for my Tamil Chorus as Kattiyakkari-Gals-a play on the English word "Gal" and the Tamil feminine plural form, Kattiyakkarigal. The members of the Tamil Chorus were professionally trained: dancers (fully versed in Bharathanatyam ${ }^{75}$ ), singers, and actors. The Kattiyakkari-Gals danced, sang, and recited poetry and provided context akin to B-Roll or cutaways in conventional documentaries. Their poetry, songs, and dance helped to provide much needed breaks from the interviews that were akin to the talking heads of traditional documentaries.

In addition, two of the Kattiyakkari-Gals were actually my nieces who revealed their meta-roles in the piece at the end of the production. Born here, they would not exist if their mother hadn't fled the conflict in Sri Lanka and come to Canada as a refugee. These two young women were part of the story as performers but also as the offspring of a Tamil refugee who taught them the language and classical dance form

\footnotetext{
${ }_{75}$ Kattiyakkaran: $\mathrm{http}: / /$ www.revolvy.com/main/index.php?s=Kattaikkuttu\&item_type=topic

${ }^{75} \mathrm{http}: / / \mathrm{www} . c y b e r k e r a l a . c o m /$ bharatanatyam/ "Bharatanatyam, also spelt Bharathanatyam, is a classical dance form of South India, said to be originated in Thanjavoor of Tamil Nadu. It was known as "Daasiyattam" since performed by Devadasies in temples of Tamil Nadu long ago. The name 'Bharatanatyam' is derived from three basic concepts of Bhava [expression], Raga [melody] and Thaala [rhythm]."
} 
that they performed. As the children of my brother, they played a meta-meta role: as performers and subjects in the documentary and within this director's personal life story.

The Kattiyakkari-Gals also performed spoken word pieces set to choreography: the evocative In The Belly Of The Cargo Ship ${ }^{76}$ and the redemptive Happyfish ${ }^{77}$, the latter of which became a continuous thread through the entire documentary. They used the opening couplets to question, elicit and set in motion the stories that followed:

$\begin{array}{ll}\text { Uprising: } & \text { Happyfish, Happyfish, } \\ & \text { What Did You See? } \\ \text { Exodus: } & \text { Happyfish, Happyfish, } \\ & \text { Where Have You Been? } \\ \text { Survival: } & \text { Happyfish, Happyfish, } \\ & \text { Who Are You Now? }\end{array}$

And the subsequent unfolding narratives within each part of the trilogy became the answers. The documentary concluded with the collective recital of the full Happyfish poem by the Kattiyakkari-Gals, Brother, and by all present-a nod to the understanding that everyone inside the space played a part in 'performing the documentary.'

\footnotetext{
76 Sundar Singh, "Script," p20

77 Sundar Singh, "Script," p31-32
} 
Earlier, in this essay I made the assertion that where there is a camera, we perform to it. Whether it is a selfie, a group shot, documentary, drama, or the six o'clock news, we are influenced by the presence of the camera. Similarly, the presence of audience can also influence the story and the storyteller. Brothers in the Kitchen allowed me to explore both these notions. By creating a construct that used a specific site, live subjects, performers, cameras and crew together with audience, these components conspired to create a unique experience involving traditional elements of documentary. It also employed novel sensory elements including, taste and smell and the kind of exciting glitches that can occur when something is performed live.

There is a heightened energy that captivates the gathered who, are not only there to receive but also to participate. And much like theatre or a religious revival meeting, the symbiosis between the storyteller/artist/preacher and the audience can seem sacred. An ephemeral bond is created during the exchange of music, song, or story. This exchange is as old as the caves and the campfires.

A filmmaker can use the above elements to influence outcomes but I maintain that it should be for creative impact, not at the expense of truth or ethics. Unlike Flaherty, who fabricated parts of his story and thus crossed a certain line, my 'second pumpkin' did not change my actual story; it enhanced it. Likewise, in Brothers in the Kitchen, the story remained authentic as told by primary sources and performance was enhanced by my creative hand and by the live interface between audience and subject.

My theoretical and practical exploration of documentary in all its forms continues to feed my creative muse. The success of the genre-bending Brothers in the Kitchen 
'live-doc' has inspired me to explore other hybrids and forms of documentary storytelling yet to be farmed, formed, and framed. Documentary, like language, is ever evolving and I want to ride that [r]evolution!

Since January 2016, while producing my live-documentary, Brothers in the Kitchen, and subsequently while writing this thesis, I have also been involved in both the planning and execution of an important reunion in Newfoundland to mark the $30^{\text {th }}$ anniversary of the arrival and rescue of the one hundred and fifty-five Tamil refugees off the Avalon peninsula in August 1986. As part of a dedicated group of Tamil-Canadians, I was given exclusive access to document the process and as a member of the planning committee I actively participated by sharing my research, ideas, connections, and knowhow. In fact, I profoundly influenced the story, even changed history, as through my research I located one of the two original lifeboats in which the 'boatpeople' first arrived. As a result of a trip to the Maritimes in July 2016, I found the fisherman who owned the boat, the fourth owner since its arrival in Canada. I advocated for the lifeboat's inclusion in the reunion itinerary. And this lifeboat became the centrepiece of the reunion.

On August 11, 2016 in Holyrood, a small fishing village, four former Tamil refugees Shanmuga Paul, Gandhi, Siva, and Baskaran climbed back into the lifeboat in which they and "[m]ore than 150 Sri Lankan men, women and children, [had been] found adrift off the coast of Newfoundland..."78 With numerous reporters and video cameras, mobile phones and iPads rolling, the four men overwhelmed, broke down,

\footnotetext{
${ }^{78}$ Star, 1986
} 
cried, and comforted each other. Thirty years after their maiden voyage, the refugees in the lifeboat made national and international news for being in that lifeboat once again. At least sixteen print media outlets from coast-to-coast plus national broadcasters CBC and CTV covered the story. That powerful documentary moment was also "received through a multiplicity of hybrid and networked screens," and "tweeted, blogged, texted and organized on Facebook..."79 I am proud to say that today their story was finally embraced with open arms. I had a hand in constructing that moment.

My intervention led to the lifeboat being acquired by the Canadian Tamil Congress and transported to Toronto, home of the world's largest Tamil Sri Lankan diaspora just in time for Tamilfest, ${ }^{80}$ the annual Tamil Street Festival in Scarborough. The lifeboat instantly became the centerpiece of the event, a touchstone for the entire community. Throughout the festival, attended by 175,000 people, two of the lifeboat's original passengers kept vigil beside it, proud ambassadors for the community, greeted by Premiere Kathleen Wynne, and Immigration, Refugees and Citizenship Minister, John MacCallum.

Before driving over to Tamilfest, I called up "Anonymous", one of the original boatpeople and the real 'brother in the kitchen' who had been an indispensable resource to me by confidentially sharing his intimate and painful journey, and allowing his words to be performed verbatim as part of my live-doc. With hopes that he may finally, rightfully join his cohorts as a proud ambassador or at least as a silent witness to the changed 2016 reception of the lifeboat, I offered to pick him up and drive him to

\footnotetext{
${ }^{79} \mathrm{Ibid}$

${ }^{80}$ www.tamilfest.ca/
} 
Tamilfest. Sadly, he declined, still too ashamed to come, for fear of being identified as an illegal immigrant, or just a lowly boatperson who simply ended up as a 'brother in kitchen."

At Tamilfest, my instrumental role in the process seemed quickly forgotten. The lifeboat's new narrative in the community did not include me. In fact, in a CBC Radio interview someone else acted as spokesperson about the lifeboat as a focal point of both the Newfoundland reunion and Tamilfest. It was no longer my story to tell. Having previously felt like a part of the story, at the festival I felt relegated to the perceived role of filmmaker simply there to document the event from "the horse's mouth" rather than shaped by an auteur of story.

Interestingly, there was a related story unfolding in real time involving the community, its leaders, and the storyteller. It was a delicate negotiation between what the community wanted to show, what the leaders wanted to shape, and what this storyteller wanted to reveal. It was then that I understood that the story and the lifeboat were larger than me; the boat became a symbol that closed the circle and celebrated the community. Moreover, the Tamil-Canadian Sri Lankan leadership purchased the lifeboat and consciously or unconsciously used it as a tool to re-stage or re-tell history to legitimize the community's arrival narrative. This was beyond my control. One could say that the story was manipulated or mediated in order to obtain the desired outcome, to serve the collective needs.

Was this life imitating art? Was this at the expense of truth? Did the end justify the means? Maybe it did justify the means as the lifeboat has taken on new meaning for 
the Tamil Sri Lankan community and Canadians at large. Its "second coming" has given Canada a second chance to properly welcome the Tamil refugees and embrace the community. With news about the lifeboat being broadcast nationally and the Premier and the Minister visiting the boat at Tamilfest, finally both the refugees and the Sri Lankan Tamil community received the official Canadian welcome that they deserved, like the one received by the Syrians from the Prime Minister. (word count 11020) 
BROTHERS IN THE KITCHEN

\author{
a documentary by \\ Cyrus Sundar Singh
}

Final Script

May 4, 2016 
SCRIPT LEGEND:

Areas for lighting/action

Position 1: (P1): Bar (Corner, just behind overhead light)

Position 2: (P2): Stage Left/High Roundtop Table

Position 3: (P3): Table in between TV monitors

Position 4: (P4): Under light in front of screen

Position 5: (P5): Behind the projection Screen

\section{Actors :}

1 "Brother" Anand

2 "Chorus1" Mira

3 "Chorus2" Gabi

4 "Chorus3" Dharshi

Musicians:

Musician 1 Ian - Bass

Musician 2 Jeetu - Bansuri

Musician 3 Santosh-Tabla/Dolak/Kangira

Vocalist 4 Mathusha

\section{Cooks :}

Cook 01: (C01) Sasi [live in Kitchen]

Cook 02: (C02) Suseela [live in Kitchen]

\section{Subjects :}

Subject 01: (P1) Amarnath (Amar) Amarasingam [live P1]

Subject 02: (S2) Sri Guggan [live P2]

Subject 03: (S3) Manjula [live P1]

Subject 04: (S4) Sunthar [live P3]

Subject 05: (S5) Kiruthiha [live P3 \& P4]

Subject 06: (S6) Anonymous [performed by Anand P5]

Subject 07: (S7) Shanmuga Paul [live P1]

Subject 08: (S8) Suresh [Playback]

Subject 09: (S9) Princy [live P3]

Subject 10: (S10) Asanka [live P3]

Subject 11: (S11) Barbara Hall [live P2]

Subject 12: (S12) Frances Harrison [Playback]

Subject 13: (S13) Bob Rae [live P2]

\section{Volunteers :}

Volunteer 1 (V1) Gus Dalton [performed Live P1]

Volunteer 2 (V2) Brian Mulroney [performed Live P1]

\section{Choreographer:}

Sudharshan Durayappah 
INT. HAPPY FISH CAFÉ (CSI ANNEX CAFÉ). LATE SPRING EVENING

The audience arrives at the Happy Fish Café for the evening's documentary experience. The space is sparsely decorated, mostly as is: a real café/restaurant. It is intimate and cozy. A range of seating options is available: chairs; couches; benches; standup tables; folding chairs; etc... Off to one side is an open kitchen with a beer/wine bar and a cappuccino bar connected. cooking smells permeate the space. The kitchen is abuzz with activity. Cooks are busily prepping several dishes that will be served to the guests. To one side of the kitchen, a small group of musicians have set up next to the bar. A number of 'vintage' lifejackets hang near the ceiling. Each of the three large square windows facing east towards Bathurst street has a red and white circular lifesaver. The people settle into their seats. An air of

excitement and anticipation is present. A camera crew is setting up to shoot the kitchen action for what looks like a cooking show. The cameras begin to frame a BROTHER [Cook/Narrator] and SISTERs [Cooks/Sasi \& Suseela] in the kitchen. The images captured are displayed on the TV MONITORS

00:00 PREAMBLE

\section{SHANE / SARAF INA}

(Hot Docs)

[welcome and housekeeping]

Welcome everyone. If you thought

you were coming to see a movie tonight, you are in for a delicious surprise. Tonight you will

experience something innovative and genre-bending created by Director, Cyrus sundar Singh. This means you are part of a one-night only, live documentary, performed right here with subjects, experts, narrators, musicians, cooks, and food. All food is vegetarian and although nut-free, we cannot guarantee it hasn't been in contact with nuts. There will also be some stops and starts and live cameras and sound recordists moving around. You are part of this from the inside-out. Please remember that tonight's performance is being videotaped and that you may be on camera. And we 


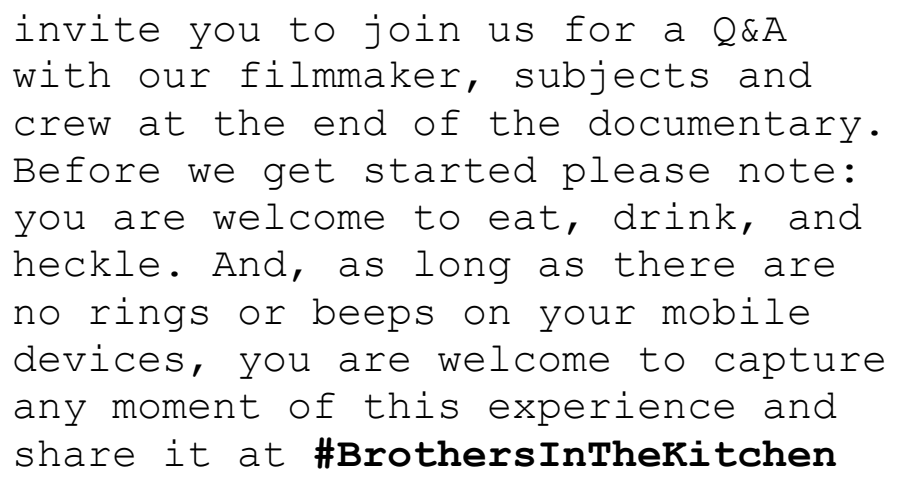

The DIRECTOR and CAMERA 2 are positioned to capture the CU of BROTHER's face. This action is seen on the TV Monitors.

\section{DIRECTOR}

Are we all ready? Roll camera $1 . .$.

\section{SHAY}

Camera 1 rolling

DIRECTOR

Roll camera $2 \ldots$

Camera 2 rolling

DIRECTOR

Roll sound

SHAUGHNA

Sound rolling

\section{DIRECTOR}

and slate!

The DIRECTOR slaps two hands together in front of BROTHER's face as a slate to the camera.

\section{0:00 PRETITLE}

The cameras pull back and on the cue of a musical note [Cue Music 1] (Bass) the TV MONITORS come alive with the sights and sounds of flames emanating from a cooking grill. A moment later, BROTHER begins to percussively "play" a pot, [Cue Music 2] which sets up an 8-bar beat. This gets 
picked up by the Dolak player and then by the CHORUS of 3 dancers Mira, Gabi and Dharshi. They enter the Café scat-singing (TaKaDiMi): Gabi enters from stage Left. Mira enters from stage Right. Dharshi enters from the Kitchen. The camera-crew re-position to better cover the dancers. The dance ends with a percussive flourish. The CHORUS breakaway creating a space in the centre for the BROTHER who steps out from behind the kitchen counter, walks up the created space and addresses the audience:

BROTHER

Vanakam. Ladies and gentlemen, welcome to the Happy Fish Café.

BROTHER pauses. The CHORUS from where they are standing:

CHORUS

(with an innocent quality)

Happyfish, happyfish where have you been?

MONITORS: Images of Tamil fishermen and catamarans are displayed on the MONITORS: [Cue Music 3]

BROTHER
For a thousand years, Tamil
fishermen have gone to sea using a
Kattumaram, a Tamil word borrowed
into English, now pronounced as:
Catamaran.

While BROTHER talks, the CHORUS tie each other together with a saree, symbolically "tying the wood".

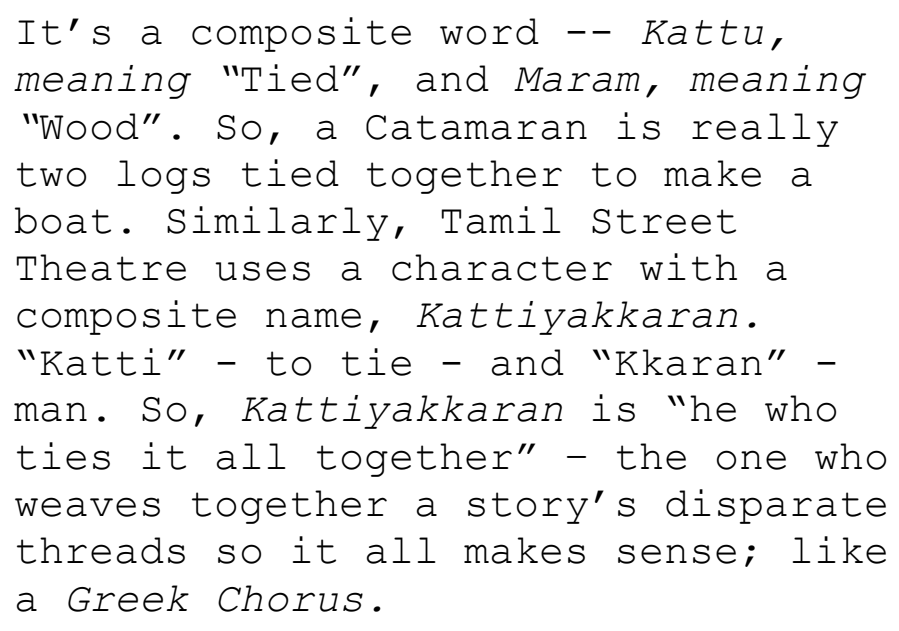


The CHORUS moves towards and around BROTHER.

CHORUS

So, we are the Chorus; the

Kattiyakkari-Gals -

They dance another jiggy, jaggy, ta-ka-di-mi stylee. The BROTHER returns to the kitchen to cook:

And with our Brothers and Sisters, Aunties and Uncles, Poets, Musicians, and all of you, we are Performing the Documentary together

live!

How cool is that?

How cool is that?

How cool is that?

Tonight, our brother in the kitchen is Anand. However, there are many Brothers all across this city -Tamil Sri Lankans working shifts in restaurants, cooking everything under the sun:

French, Italian and Greek; Pubs, Clubs and Subs;

Battered, Blackened and Barbequed;

BROTHER

Thai, Jerk and Deli --

CHORUS

Toronto's restaurant industry is built on the shoulders of these unsung heroes.

CHORUS WALKS OVER TO the BROTHER

CHORUS

That smells good. What are you cooking?

BROTHER

On the grill today, we are serving up a trilogy: the Uprising, Exodus, and Survival of a minority. No scales, no bones -- just flesh served hot, firm and spicy...

(C) 2015 Cyrus Sundar Singh \& Salaam Shalom Productions Inc. cyrusmedia@pathcom.com 


\section{[Cue Music 4]}

The Chorus directs the audience's gaze towards the TV MONITORS. A 30-second title sequence with a collage of brothers working in various restaurant kitchens is displayed, ending with the on screen title: "BROTHERS IN

\section{THE KITCHEN"}

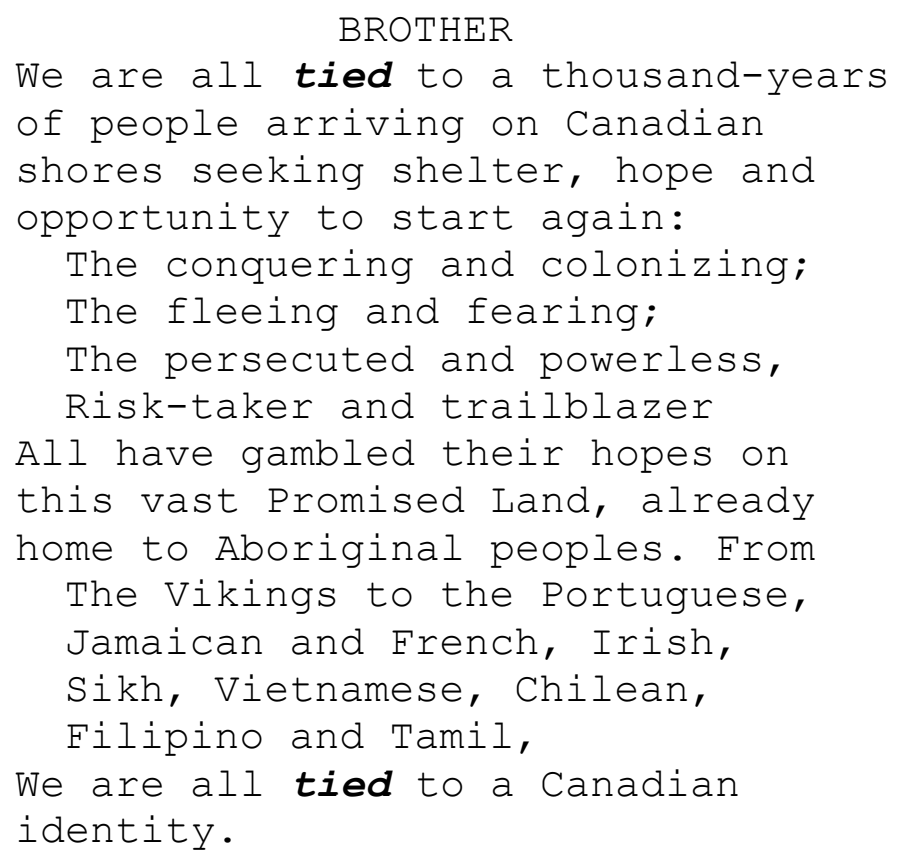

[Cue Music 5] Back to BROTHER:

[BROTHER uses the Toronto Star Newspaper as prop.]

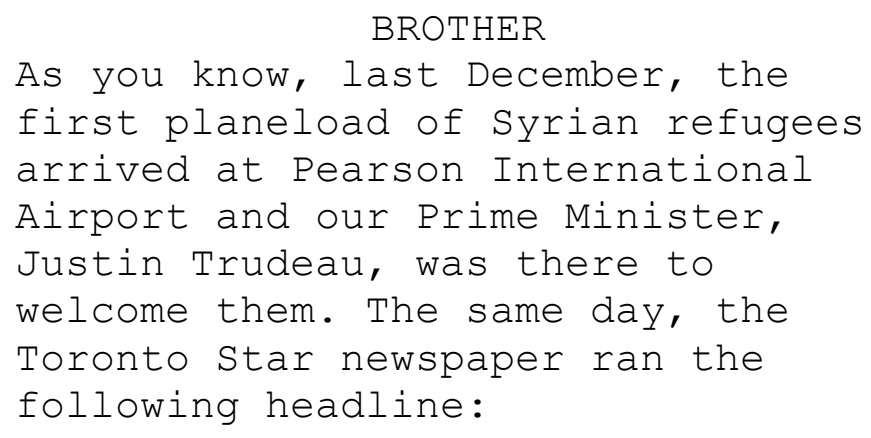

BROTHER continues to read in silence. The CHORUS read out loud from their own newspaper copies: 
CHORUS

"As 150 refugees land at Pearson

today - among the first of 25,000 -

on behalf of the star and our

readers, we say: WELCOME TO CANADA"

[Cue Music 6]

\section{BROTHER}

The Syrians fled a brutal civil war

and came seeking shelter, hope, and

a new beginning...

... Now, let's go back thirty years

to 1986 when 155 Tamil Sri Lankan

refugees arrived on the Eastern

shores of Canada. They too fled a

brutal civil war and came seeking

shelter, hope, and a new beginning:

[Cue Music 7] the CHORUS gestures tOWARDS THE MONItORS. THE

TITLE "ACT 1,UPRISING" APPEARS AND DISSOLVES INTO IMAGES

OF ROUGH WATERS WITH A BOAT COMBINED WITH SOUNDS OF

CRASHING WAVES. THIS IMAGE CUTS TO ARCHIVAL FOOTAGE FROM CBC TELEVISION NEWS:

\section{KNOWLTON NASH [Archival]}

CBC NEWS ANCHOR

Good evening. There's a big mystery

off our east coast tonight. A

Canadian fisheries boat is now

rescuing about 150 people from

lifeboats off the coast of

Newfoundland but we don't know if

the ship they were on sank or

whether they asked to be put off

board to try to settle in Canada.

$[00: 15]$

The archival footage dissolves into ocean waves which in turn dissolve into an animated google earth map that zooms out from Canada and glides over to Sri Lanka.

\section{[Cue Music 8]}

BROTHER

Sri Lanka, formerly known as Ceylon, the island jewel off the southern tip of India's necklace, was embroiled in

(C) 2015 Cyrus Sundar Singh \& Salaam Shalom Productions Inc. cyrusmedia@pathcom.com 
a protracted and devastating civil war that had polarized its citizens along ethnic lines - a Sinhalese Buddhist majority, and a Tamil Hindu minority.

After the nation's independence from Britain in 1948, the Sinhalese expressed pent-up hostilities towards Tamils by passing several highly discriminatory regulations.

In response, Tamils agitated for a separate state. Tensions exploded into ongoing, communal violence resulting in tremendous casualties and suffering on both sides.

University of Waterloo Lecturer Amarnath Amarasingam, sheds further light and historical context.

\section{AMAR (S1/P1)}

[Brief context about the history/foundation - land of indigenous people, Sinhalese and Tamils Colonial Rule - Portuguese, Dutch allowed Sri Lanka's three sovereign states to be "ruled as separate entities..." Later, however, under British rule, the 3 states became 1 administrative body, creating conflict between these historically warring peoples. After Independence from Britain in 1948, things worsened due to the introduction of policies by the Sinhalese government that disadvantaged Tamils. In 1956, for example, Sinhala was made the official language under the Sinhala Only Act. This led to the 1958 riots, where thousands of Tamils were slaughtered and displaced.] This conflict continued for decades and, eventually in 1976, a guerilla group was established called the Liberation Tigers of Tamil Eelam - 
commonly known as the LTTE or the

Tamil Tigers. Their goal was to

establish an independent Tamil

state, or Eelam, in northern \&

eastern Sri Lanka.

BROTHER

Communal violence erupted in 1956

and 1958. Toronto Tamil elder, Sri

Guggan, recalls his experiences.

[CUE MUSIC 9]BROTHER walks over to P2.

SRI GUGGAN (S2/P2)

On May 25 1958 , when I was 15 years

old, 70 Tamil people sought refuge

at my parents' home in the outskirts

of Colombo. They were running away

from a Sinhalese mob of about 3000

looking for blood. They were finally

rescued by a platoon of [SINHALESE]

Army volunteers. They first saved

the women and children and then came

back for the men.

\section{BROTHER}

Violence continued in '67, and in

'77. But in 1983, Similar Army

volunteers disarmed the Tamils and

then handed them over to the

Sinhalese rioters.

...and in July 1983 when Tamil rebels

killed 13 Sinhalese soldiers - all

hell broke loose.

For 7 days and 7 nights, there was

killing, rioting, burning and

ethnic cleansing - in what is now

known as Black July.

[Cue Music 10] MONITORS playback of map and sequence with music embedded. Cuts into playback of MANJULA ON-MONITOR and SLATE with musical HIT for Transition:

$$
\begin{gathered}
\text { CHORUS } \\
\text { (with dark anticipation) }
\end{gathered}
$$


Happyfish, happyfish, what did you see?

I am Manjula.

MANJULA (S3/P1)

It came all of a sudden. Vanloads

of loud men started driving down

the road. My parents were scurrying

around the backyard trying to

figure out a way to escape. A group

of men had gathered outside our

home, throwing stones and breaking

windows, while others started

pouring kerosene on the house. I

also saw a few outside with axes

and other weapons. Seeing that they

were setting fire to the place, we

knew we had to leave. There were

about 13 of us in that bedroom, the

five from my family, five from my

aunts' family, two other cousins

and some girl I vaguely remember

that had been left with us for

safekeeping .

Taking up the offer of shelter from

a Catholic Sinhalese neighbor

behind us, we scaled the back wall

and hid in their house overnight,

as our house was first looted and

then put on fire. That night a big

argument broke out in front of

their house because some of the

other Sinhalese neighbours wanted

the kind lady to throw us out on

the street to fend for ourselves.

There were dead bodies on the main

street; one of my Tamil girlfriends

was chased by a mob and managed to

escape; another friend saw a woman

being burnt alive on the streets.

THE CHORUS RETURNS TO FACE THE AUDIENCE. DIRECTOR INTERVIEW

CHORUS

(with dark anticipation)

Happyfish, Happyfish, what did you see?

(C) 2015 Cyrus Sundar Singh \& Salaam Shalom Productions Inc. cyrusmedia@pathcom.com 


\title{
SUNTHAR ( S4 / P3)
}

I am Sunthar. I was on my way home, I saw the mobs armed with iron rods and petrol cans torching cars, attacking people, looting shops and there were so many people carrying away things they had plundered and pillaged from Tamil shops and houses. Many of them were dancing in the street and it was a bloodcurdling experience to me. Apart from the killings, houses were burnt, hands were chopped off, legs broken and it was an endless litany of mob ruthlessness. All these happened within a day. And all these were happening in front of the police and the armed forces who were watching, without taking any action.

\section{[Cue Music 11]}

\author{
KIRUTHIHA (S5/P3) \\ I am Kiruthiha. My family were \\ survivors of the 1958 and 1977 \\ riots. However, this time it felt \\ like a whole different experience. \\ This time the riots were exactingly \\ executed from a government \\ perspective and was not just some \\ spontaneous emotional response on \\ the part of a community, as how the \\ media portrayed it. \\ On that Sunday prior to the riots, \\ we had heard that the bodies of the \\ 13 soldiers killed in Jaffna were \\ supposed to come to Colombo for \\ burial. This itself was highly \\ unusual as the bodies are usually \\ sent to the family homes. Though we \\ were concerned there could be an \\ issue starting in Jaffna, it never \\ occurred to us that problems could \\ start in colombo, since we always \\ thought colombo as metropolitan and \\ diverse city - a tourist hub.
}


On Monday, one of our neighbours came back from work early in that morning, and told us that problems were starting in the northern part of the city. He told us to put our jewelry and other valuables in the bank. Very soon, my grandfather arrived from his work and informed us that we could not leave because the local Tamil grocery shop at the top of the main road is burning.

My grandmother, who had survived the 1958 and 1977 riots started packing up the jewelry and putting it in the pockets of her saree underskirt. She had always sewn pockets into her saree underskirt for this purpose, and I was just amazed at her survivor skills. My mother packed our passports, tickets, and money. It never occurred to me as to what I could do, since I was just 12 years old. I thought the whole scenario would blow away in half hour.

Then the screams started. It came from our neighbours in front and to the right. There was also the smell of the fire and smoke. The screams were like a movie, and my mother used to tell me movies were fake; I knew now she lied.

My mother is very laid back and quiet. This was the first time I saw her take leadership. My grandfather refused to leave the house, since it was the house he and my grandmother built together. My grandfather at that time had retired from the Police service, a past inspector for the Wellawatte station and was working for a security firm. 
My mother was leading me, my

grandmother and neighbours who were in our house, through a gate in our back yard. Her intention was to go to our neighbour's house who were Sinhalese, but they shut the door as they saw us coming. Therefore we went across the lane into a house where the front door was open and there was a Sinhalese widow living there. It was just a twist of fate that the front door was open. My mother never knocked or asked for permission. The widow was ready to throw us out but after hearing my mom's pleas - she finally gave in.

The lady took us to a tiny store room at back of the house. It felt like an eternity in there as you heard the screams, the explosions, gunfire and smoke. I remember sitting and peeking through the window, and seeing a guy in a sarong and vest, his arms were filled with golden thalis (necklace worn by married Tamil women). He looked so pleased with himself. I remember wondering whether he killed those women for the thalis since I could not imagine any Tamil woman giving them up willingly. It never occurred to me that I too could die. My mother's biggest fear was that I was going to be raped. She never spoke of it to me whilst we sat huddled in that room but I knew and felt her fear. All I felt was this sense of despair that all these people out there hated me not for anything I did or my family did but for the only fact that I was Tamil. I felt that we were outcasts, and that we were not worthy of fundamental humanity. 
Then we heard the thumping, and we knew the thugs had come into this house, and you could hear the voices. They asked the widow if she was hiding anyone, and she stated, "Do I look like I'm hiding anyone? I'm an old women, I don't like Tamils either." With that, they left. However, the widow did not want us to stay there anymore either.

We decided it was time to go to the Ramakrishna Mission, which is barely 100 meters from our house. We got as many people together and my mother was leading the way. When I attempted to run back to get my dog, I saw Sinhala Buddhist monks among the rioters with large weapons. To me, even at that young age this image was not right. I am yet to identify any other country in this world where a Buddhist monk would look at me with such murderous rage in their eyes. I immediately ran back to my mother.

The Swami at the mission welcomed us and led us to the hostel in the back for safety. Many other families fleeing the terror had already found shelter there. As I looked out the back window, I saw trains stopping at unscheduled stops along the railway. It was quite strange. I watched in mute disbelief as men with weapons and petrol cans were getting off these trains. I remember struggling to understand why the train driver would help the thugs, now I know better. It was all already planned well in advance.

Late into the evening, a Swami rushed in informing us that the 
main shrine was no longer safe. The angry mob was inside and had already hurt the chief Swami and damaged the pictures in the shrine. We were told later that trucks were being driven in to take us to refugee camps. We were loaded onto the trucks as if we were cattle to be driven to slaughter. I hated the feeling of not knowing who was driving and where to. It made me feel helpless, and angry. I was made to stand towards the back of the truck facing outwards so that I could breathe as I was one of the few children on this truck.

As the truck turned onto Galle road, I saw thugs walking with knives and the armed forces in their uniforms. There were not many civilians on the road; just broken shops aflame. And that's when I saw a human form being burnt alive. I couldn't make out if it was male or female but I could see the head, torso and legs. It was still

moving. A person, who had family somewhere, with dreams and hopes was being burnt like trash in the middle of the road. In their eyes, we Tamils were trash. I felt shock and my gasp was silenced by a hand from behind me that remained on my mouth for the duration of this painfully haunting journey.

[Cue Music 12] MATHUSHA, standing at the microphone stand at position 4 sings a haunting Tamil melody. The CHORUS, each holding a votive candle/light, stands with MATHUSHA as she sings. An edited sequence depicting the violence of Black July is shown on the TV monitors. MATHUSHA sings a vocal intro and one verse of the song. Over MATHUSHA'S final vocal interlude, the edited sequence on the TV MONITOR dissolves into the title: ExODUS, which then dissolves into images of rough waters with a boat combined with the sounds of crashing waves. MATHUSHA finishes 
singing. The chorus blow out/turn out the lamps/lights. The image on the MONITOR cuts to archival footage from CBC Television news [03:00]:

KNOWLTON NASH

CBC NEWS ANCHOR

Good evening. There's a big mystery

off our east coast tonight. A

Canadian fisheries boat is now

rescuing about 150 people from

lifeboats off the coast of

Newfoundland, but we don't know if

the ship they were on sank or

whether they asked to be put off

board to try to settle in Canada.

Kathryn Wright reports:

\section{KATHRYN WRIGHT \\ CBC REPORTER}

When the fishermen spotted the

lifeboats, they were about $10 \mathrm{~km}$

West off St. Shotts on the Southern

tip of the Avalon Peninsula. There

were 152 people in two lifeboats-

mostly men but four women and five

children. Most appeared to be in

good health. One man said he was

Chinese. Another said he was from

Sri Lanka. They said they'd been

adrift for five days.

BERNIE LEONARD

CANADIAN COAST GUARD

Some people are in a weakened

condition. Some seem to be

debilitated. Some seem to have

problems with vomiting and

dehydration.

\section{KATHRYN WRIGHT CBC REPORTER}

The fishermen were instructed by the coast guard to take the people on board their longliners but for security and immigration reasons they were told not to take them to land. Instead they were asked to 
wait for the fishery's patrol boat, the Leonard J Cowley, to pick them up. The cowley is now bringing the people to st John's.

Earlier this evening, immigration officials, the RCMP and the coast guard got together to figure out how to handle this case. Some suspect it's either a refugee case or at the very least a deliberate attempt to get into the country.

BRUCE REID

CANADIAN COAST GUARD

Well normally a lifeboat would have the name of the ship's it's off or registration number or identification number and the early reports we have are that the longliner captain that picked them up found no markings or anything on board those lifeboats. They had been scraped off. So you know it makes it seem a little more suspicious.

\section{KATHRYN WRIGHT CBC REPORTER}

The coast guard received no distress signal from any ship, all the more reason to suspect there was no disaster but that the people were in the lifeboats because they wanted to be, or because they were forced in for other reasons.

The fisheries patrol boat is due in St John's early tomorrow morning and then immigration officials will take over, they'll have translators and they'll try to find out just where the people are from and how it is they ended up in lifeboats only $10 \mathrm{kms}$ off Newfoundland's shores. Kathryn Wright CBC News St. Johns [02:41]

(C) 2015 Cyrus Sundar Singh \& Salaam Shalom Productions Inc. cyrusmedia@pathcom.com 
[Cue Music 13] On the TV MONITOR the archival CBC News dissolves into an animated Google earth map that zooms out from Canada and glides over to Sri Lanka and zooms into the Northern city of Jaffna and holds on a frame. While the above is seen on the MONITOR, the CHORUS moves the coat rack into place and hangs a white saree onto it creating a screen. The light from a projector (backlit) fills the SCREEN projecting a looped video sequence of waves. BROTHER steps behind the SCREEN and is seen in silhouette. He is now ANONYMOUS:

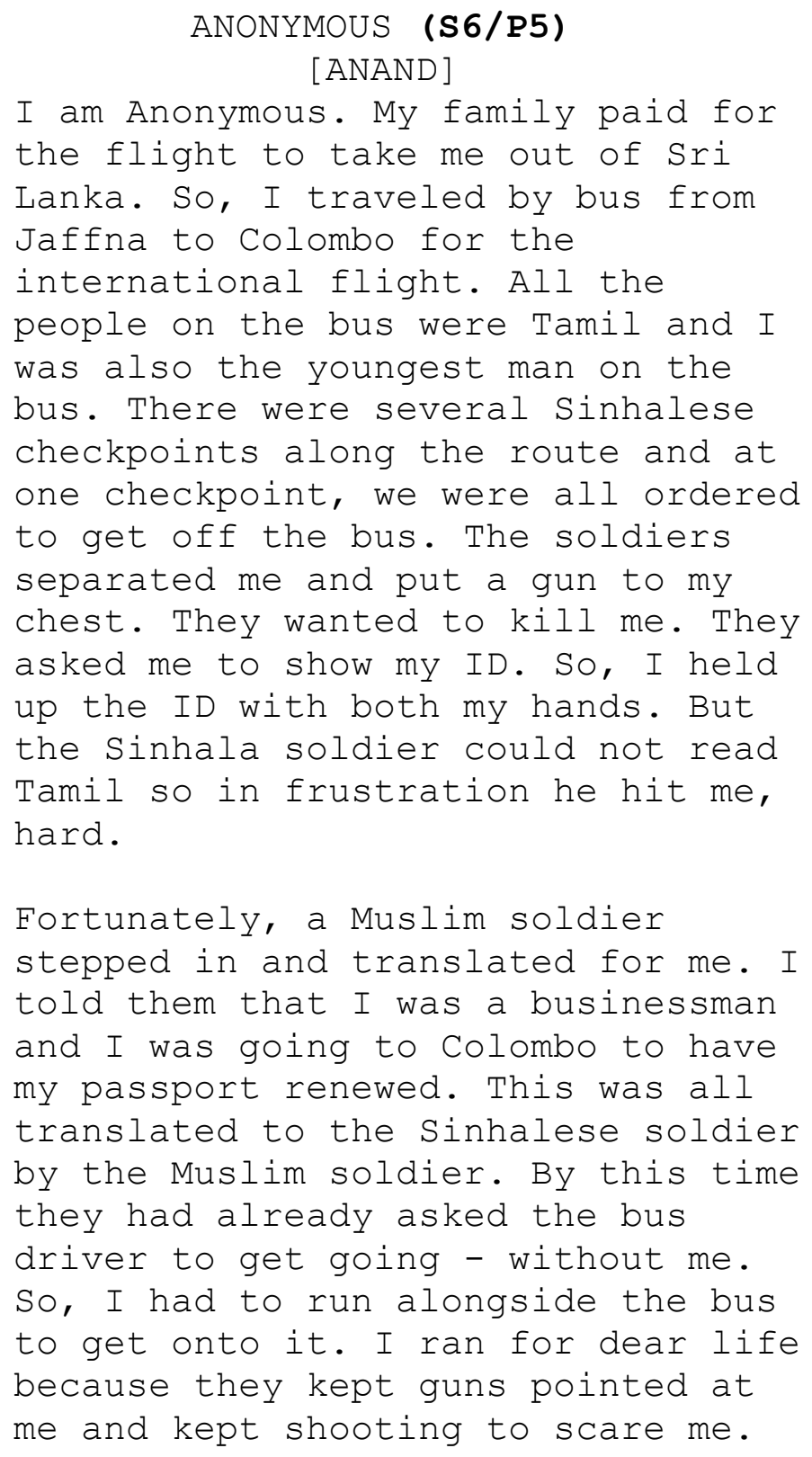


I finally managed to get on the bus, got to colombo and caught a flight to East Berlin. Then by train into West Berlin where I claimed refugee status and was sent to a refugee camp. I spent 22 months in German refugee camps. I only learned to cook in Germany in the refugee camps. Before that I did not even know how to make coffee or tea.

There I heard about an agent who could get us passage to Canada on a cargo ship for 5000 DEUCHMARKS. I paid 3000 DEUCHMARKS, and the rest after I landed in Canada. I had to borrow the money. In total it cost me $\$ 16,000$ Canadian.

While ANONYMOUS tells his story, the DIRECTOR has brought

SHANMUGA PAUL to position 1 and has set him up for an interview. SHANMUGA PAUL is standing. Once ANONYMOUS is finished, the action CUTS to:

SHANMUGA PAUL (S7/P1)
[tells his story of leaving Jaffna
by plane into Germany and finally
buying passage onto the same ship
that landed in Newfoundland - he
was also travelling with a young
woman whom he was asked to
safeguard on the journey. He tells
of the hard voyage, the dirty boat,
the unsanitary conditions and hope
and prayers. Finally when they
thought they'd arrived in Montreal,
they were ordered off the ship and
into 2 lifeboats. They were told
that they'd see land in 2 -3 hours.
He did not think they would make it
to shore alive but there were some
Tamil fishermen, also on the
lifeboats who assured them that all
would be well. He even had to help
a young girl to pee off the boat.


[Cue Music 14] While SHANMUGA PAUL is speaking, each member of the CHORUS has embedded herself into the audience - their positions are opposite their original opening positions at the outset of the show. On DIRECTOR's cue, SHANMUGA PAUL's interview pauses and the CHORUS performs the following spoken-word:

\author{
CHORUS \\ (spoken-word) \\ In the belly of the cargo ship we \\ held, \\ Our breath, our noses, and each \\ other. \\ A village born of need and \\ circumstance, \\ Not earth or roots where we used to \\ stand. \\ Floating to the lure of the \\ Promised land - \\ Montréal, in three to four days. \\ In the belly of the cargo ship we \\ held, \\ Our breath, our noses, and each \\ other. \\ In the belly of the cargo ship.
}

GABI and MIRA move to position 1. Dharshi moves into the kitchen.

[Cue Music 15] CUT TO: Position \#5 where ANAND is still silhouetted against the SCREEN with video footage:

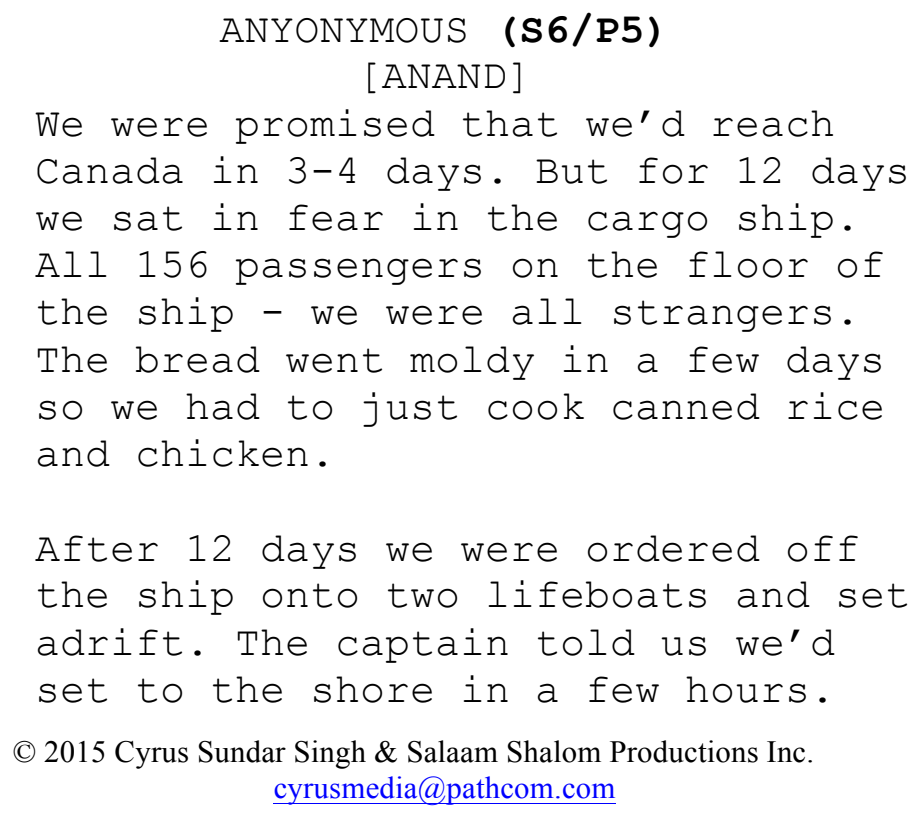


... For 3 more days, we drifted in lifeboats with no food or water.

No land, no help, no hope. We were cold and hungry. We only had the clothes on our backs.

On top of that, we were so crowded

that we couldn't even move in those boats. 78 people crammed shoulder to shoulder in each lifeboat, wondering if we will make it alive. We didn't eat or shit - just sat there cold and hungry. Each time a huge wave hit the boat and tossed us way up and down, we thought that was the end...

We constantly invoked the names of our Gods and hoped that our faith would carry us to shore. No land, no help, no hope.

[Cue Music 16] POSITION 1. TAMIL SONG - KADAL KONTHALITHU - DUET BY GABI \& MIRA. (02:00).w/Guitar Cyrus CUT TO:

\section{ANYONYMOUS (S6/P5)}

[ANAND]

Three days later, we saw a flare in the air and then the fishing boat. It was so foggy we couldn't see anything .

The fisherman lit a torch; that's how they were able to see all of

CUT TO:

us. They towed us to shore.

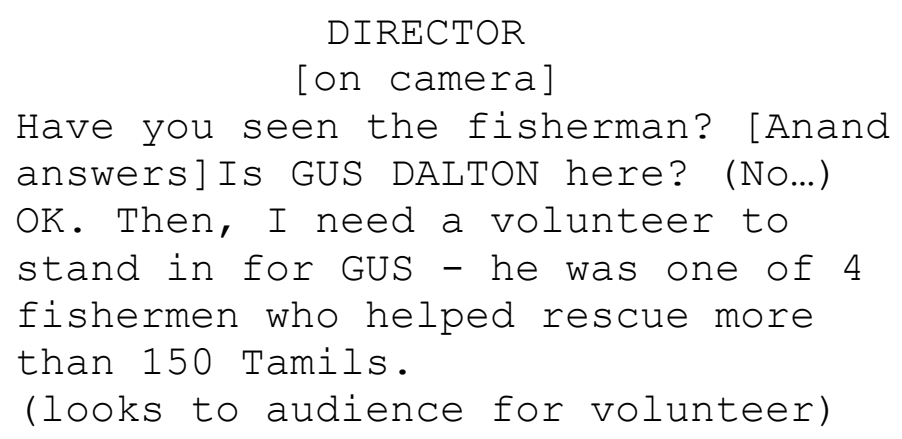




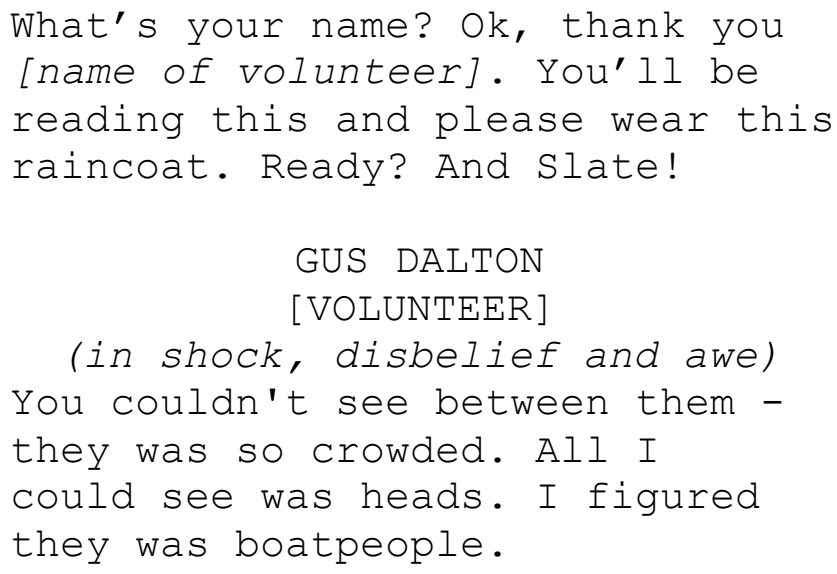

[Cue Music 17]: ON MONITOR IMAGES OF TAMILS DISEMBARKING SHIP while DIRECTOR GESTURES VOLUNTEER BACK TO SEAT. DIRECTOR GOES TO P1 TO JOIN SHANMUGA PAUL.

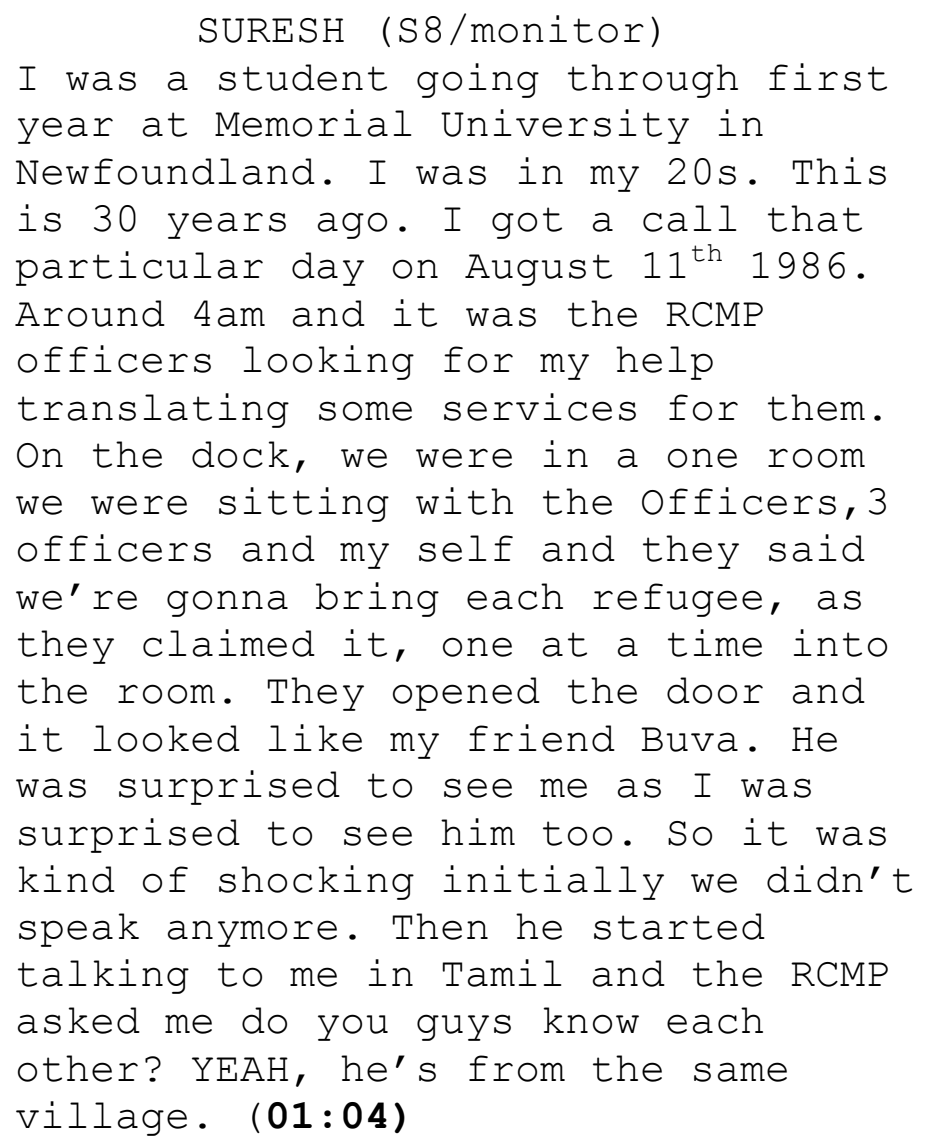

[Cue Music 18]

CHORUS

Exhausted and hungry, SHANMUGA PAUL, also known as BUVA, finally stepped 
off the Coastguard ship onto

Canadian soil.

\section{[Cue Music 19]}

$$
\begin{aligned}
& \text { KIRUTHIHA (S5/P2) } \\
& \text { One of the neighbours was a Tamil } \\
& \text { Muslim man and he managed to book } \\
& \text { two seats for us on an outbound } \\
& \text { flight to Dubai. ... We left during } \\
& \text { the middle of night and the Tamil } \\
& \text { Muslim man took us to Katanayake } \\
& \text { airport telling us to pretend to be } \\
& \text { members of his family, as the } \\
& \text { Muslims were being spared in the } \\
& \text { riots for some unimaginable and } \\
& \text { divisive reason. People appeared in } \\
& \text { all forms. I was going to board the } \\
& \text { plane in a dirty dress and Bata } \\
& \text { slippers but I was still one of the } \\
& \text { lucky ones who had such options. } \\
& \text { People were going all over the } \\
& \text { world. The airport itself felt like } \\
& \text { a refugee camp and tension was rife } \\
& \text { in the air. I never felt safe. }
\end{aligned}
$$

On MONITOR view of Princy and Asanka.

I am Princy.

$$
\text { PRINCY (S9/P3) }
$$

$$
\text { ASANKA (S10/P3) }
$$

I am Asanka.

Cut to live DIRECTOR WHO INTERVIEWS PRINCY WITH ASANKA AT HER SIDE.

\author{
PRINCY (S9/P3) \\ I left Sri Lanka as a child. \\ [She recalls that as a child of 6 \\ or 7 she, her mother and brother \\ pretended to be family with a fake \\ dad who was really an agent whom \\ their mother had paid $\$ 25,000$ to \\ escape from Sri Lanka to come to \\ Canada.
}

(C) 2015 Cyrus Sundar Singh \& Salaam Shalom Productions Inc. cyrusmedia@pathcom.com 
It was a long journey starting in

Jaffna, to Singapore to Egypt to

France to Germany to Canada.]

[Cue Music 20] - MUSICAL STING

BROTHER (MAINSTAGE)

Regardless of how Tamil refugees

reached Canada, they were faced

with many challenges, including the

view of some Canadians that these

Tamils were just economic migrants

who had cheated the system. When it

became clear, for example, that the

ship that arrived in Newfoundland

had come directly from Germany,

there was backlash.

TORONTO STAR NEWS ARTICLES ON MONITOR: CANADA'S RESPONSE \& TREATMENT OF TAMIL REFUGEES

\section{CHORUS}

Toronto Star, headlines 1986:

"Castaways deny German link: 'We are

telling you the truth'"

"Ship that smuggled 155 Tamils now

flying West German flag"

"Group 'regrets' lying to Canada

spokesman says"

"Opposition demands Sri Lankan envoy be investigated"

"Show compassion for Tamil refugees

Mulroney urges" ... to the surprise of

many and against the advice of

members of his own political party.

\section{DIRECTOR \\ [on camera]}

CUT ... Mr. Mulroney is unavailable;

he never replied to my email. So I

need a volunteer to read what he

said in Parliament. You - what's

your name? [name of volunteer] ok,

thank you. You'll be reading this

and please drape yourself with this

flag. Please stand right here and ...

ready? SLATE! 
ON THE TV MONITORS WE SEE ARCHIVAL IMAGES OF FORMER PRIME MINISTER, BRIAN MULRONEY.

\author{
BRIAN MULRONEY (P1) \\ [VOLUNTEER READER] \\ To think that, in some way, 155 Sri \\ Lankans will diminish our \\ citizenship and ruin our \\ immigration policies is not the \\ resilience and strength of Canada. \\ But I can tell you this - that \\ Canada was built by immigrants and \\ refugees, and those who arrive in \\ lifeboats off our shores are not \\ going to be turned away. \\ DIRECTOR \\ [on camera] \\ ...Cut!...Thanks [NAME OF VOLUNTEER]
}

[Cue Music 21] END OF ACT 2. COOKING OF ONE DISH IN THE

KITCHEN. BROTHER AND CHORUS ENGAGE IN COOKING ACTIVITY. AS

IT WRAPS UP, BROTHER WALKS TO P5 AND TAKES POSITION BEHIND

$\operatorname{SCREEN}(04: 00)$ [Cue Music 22]

\title{
ACT3 SURVIVAL [ON MONITOR TITLE "SURVIVAL"]
}

\author{
CHORUS (Mainstage) \\ Happyfish, Happyfish who are you \\ now?

\section{ANONYMOUS (S6/P5)} \\ [ANAND] \\ Although it has been thirty years \\ since we arrived, I still feel \\ ashamed. If we had arrived by \\ airplane we would feel better. In \\ the early days, the white people \\ would shame us for arriving on a \\ boat. They called us "boatpeople" \\ and used it as a demeaning and \\ subjugating term. I worked in the \\ kitchens as a prep cook and got \\ into many arguments with the bosses \\ about the condition of our arrival. \\ I tried to tell them the story but \\ they did not want to hear it. They
}


accused us of being so poor that we were opportunists who jumped the queue for a better life. We did not want to leave -- we had to leave-or die!

\section{SHANMUGA PAUL (S7/P3)}

I worked wherever I could. I drove cab, I delivered pizza; I worked many different jobs but I would never take a handout. I still have the very first welfare cheque that I received from the Canadian government. I never cashed it.

\section{Director cues BARBARA HALL seated at P2:}

\section{BARBARA HALL (S11/P2)}

Some of you may know me. I'm Barbara Hall. I served as both a City Councilor and Mayor of this City... Speaks about her neighbourhood, St. Jamestown, as ground zero for the new Tamil community in Toronto when she was a City Councilor starting in 1985, up to becoming the Mayor in 1994. Hall saw the neighbourhood transform with Tamil grocery shops, Tamil restaurants, a Tamil library and Hindu Temple. She relates a story of a surge in water usage in the st. Jamestown community housing units... Reinvigorated the neighbourhood; enriched our city.

[Cue Music 23] AMAR is seated at a barstool at P1.

\section{$\operatorname{AMAR}$ (S1/P1)}

This is from my book Pain Pride and Politics:

One day in the early 1990s as I was arriving home from school, I took the elevator up to my family's apartment in Toronto and saw two nondescript men at our front door. They looked as if they had been knocking for quite a while and were 
growing increasingly irritated that no one was answering. I was

surprised, as I knew my parents

were home. I walked around the men

and fumbled around for my keys.

"Who are you?" they asked. "I think

the question is, who are you?" I

responded, young tough guy that I

was. As I opened the door and

walked in, my parents also came to

the front door, presumably hearing

the quasi-argument taking place.

"We would like to talk to you--can

we come in?" asked one of the men.

"We have no money. It's pretty

tough these days." My parents

replied, apparently already aware

that these men were collecting

money for the Liberation Tigers of

the Tamil Elam (LTTE). They stood

at the front door and asked to come

in for such a long time that my

parents relented. The two men came

inside and, while seated on our

couch, explained their presence:

the Tamil Tiger leadership needed

our help, they said, and they would

like us to make a small donation,

perhaps even a monthly commitment.

CHORUS

(embedded in audience)

Happyfish, Happyfish who are you

now?

\section{[Cue Music 24]}

\section{BROTHER (P4)}

Meanwhile back in Sri Lanka, the protracted Civil War continued unabated. Both Tamils and Sinhalese were armed to the teeth. There was horrific carnage on both sides and civilians continued to pay the price. The peace process had failed and generally, the international community seemed to have little interest. 
ON MONITOR FOOTAGE OF TAMIL PROTEST ON TORONTO'S GARDINER EXPRESSWAY .

In an attempt to prevent further horrors, in May 2009, Canada's

Tamil diaspora united in unprecedented protest including in in Toronto where several thousand marched on the Gardiner Expressway blocking traffic for close to 5 hours. The phrase "I was on the Gardiner" resonates powerfully within the community, even to this day .

\title{
[Cue Music 25]
}

\author{
BROTHER (P4) \\ British journalist FRANCES HARRISON \\ writes of Sri Lanka 10 days after \\ the protests on Toronto's Gardiner \\ Expressway:

\section{FRANCES HARRISON [MONITOR]} \\ That afternoon was pregnant with \\ malice, the weather oppressive and \\ sultry. A tropical storm hung in \\ the air, waiting to explode above \\ the tiny strip of golden beach at \\ the north-eastern corner of the \\ island of Sri Lanka. It was 18 May \\ 2009. Four Catholic priests in \\ grubby white robes with black \\ sashes had just come out of bunkers. \\ They carried a white flag and held \\ their hands in the air. Terrified, \\ they knelt on the hot sand. They \\ were surrounded by dozens of \\ emaciated children in ragged $\mathrm{T}-$ \\ shirts: orphans in their care, some \\ of them in blood-soaked bandages. \\ All were pleading for their lives \\ with the Sri Lankan soldiers who \\ had their guns trained on them from \\ across the beach. \\ The stench of decomposing flesh and \\ burning tires hung in the air,
}




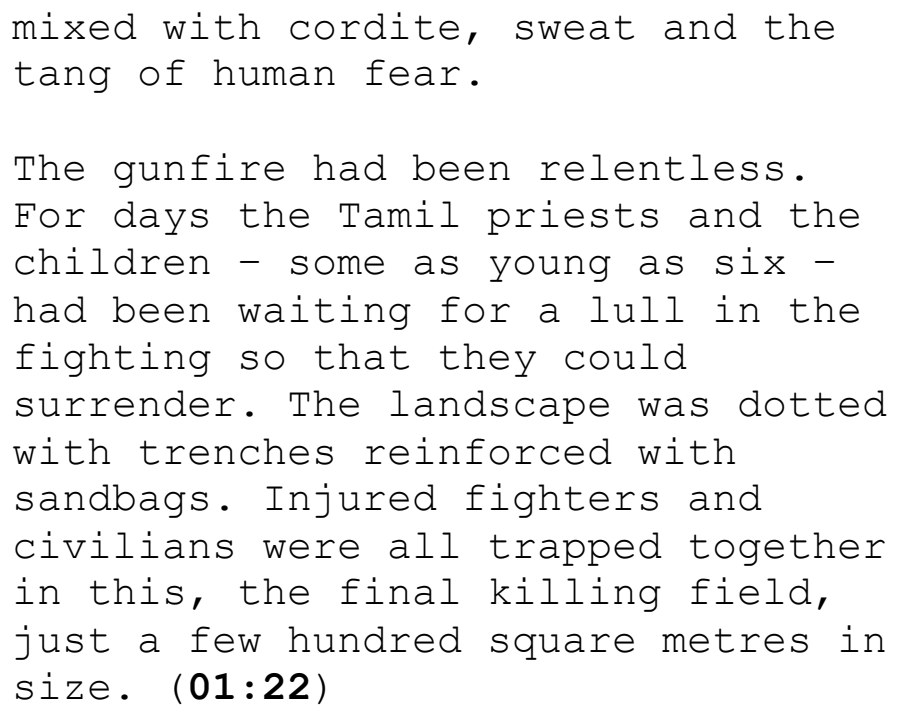

[Cue Music 26] CHORUS perform aggressive, militant war dance $(00: 45)$

\section{[Cue Music 27]}

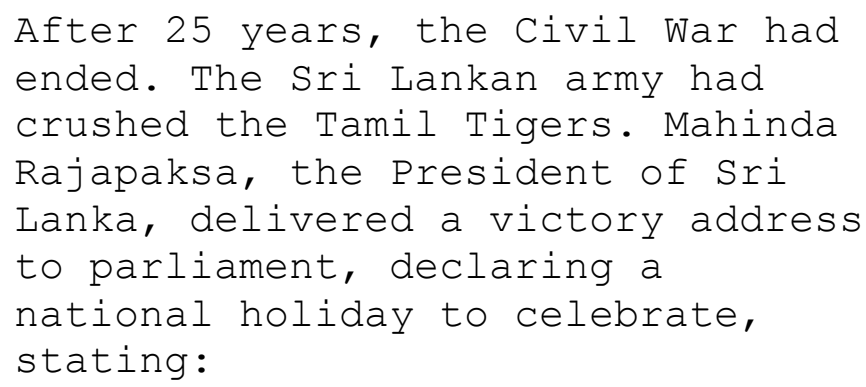




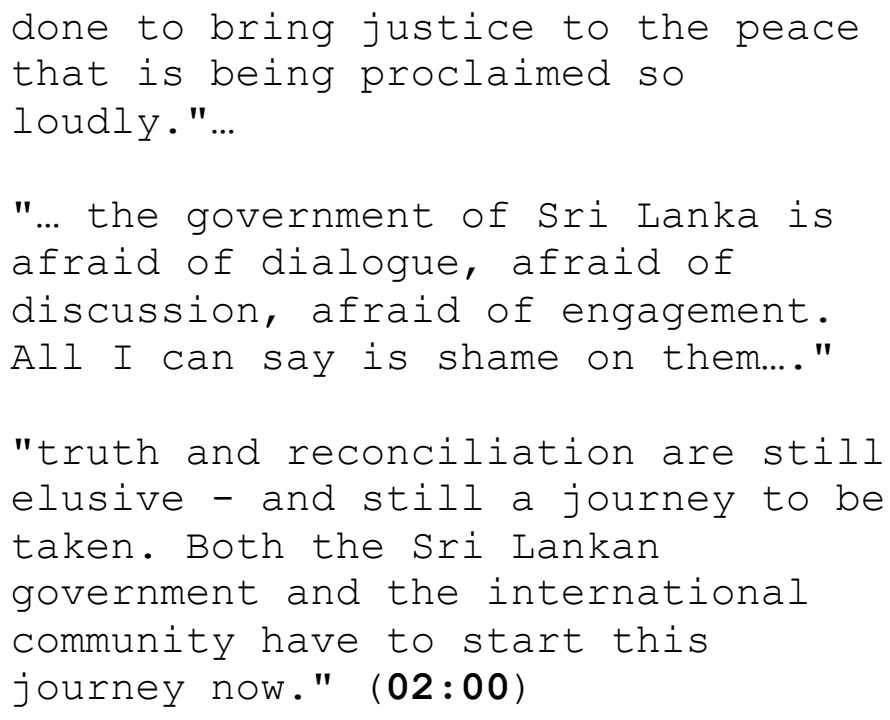

[Cue Music 28] DIRECTOR interviews couple at P3.

$$
\text { PRINCY \& ASANKA (P3) }
$$

HE IS A SINHALESE BUDDHIST; SHE IS

A HINDU TAMIL. LOVE TRANSCENDS

ANYTHING - EVEN COMMUNAL LINES

[02:00]

[Cue Music 29] CUE MUSIC AND CHORUS AND SAREE

BROTHER

Through uprising, exodus and

survival, the Tamil diaspora in

Canada has risen from the ashes,

like a phoenix, from refugees to

elected members of parliament in

one generation...

DHARSHI steps forward:

\title{
DHARSHI
}

...And note, Tamil-Canadian is a

composite word. Yes, we're all tied

together.

DHARSHI steps back leaving GABI \& MIRA as the focus:

\section{[Cue Music 30]}

\author{
GABI \& MIRA \\ Ironically - the two of us would \\ not exist - would never have been \\ (C) 2015 Cyrus Sundar Singh \& Salaam Shalom Productions Inc.


born - were it not for Sri Lanka's

horrificconflict. Our mother,

Mangala Kumari was forced to flee

her home - but gained a new home in

Canada.

The CHORUS/BROTHER make their way to mainstage and address the audience. The CHORUS invite the audience to participate in performing the Happy Fish poem. The audience is invited to ask the four questions, which are also displayed on the MONITORS. They conduct a trial run and then begin:

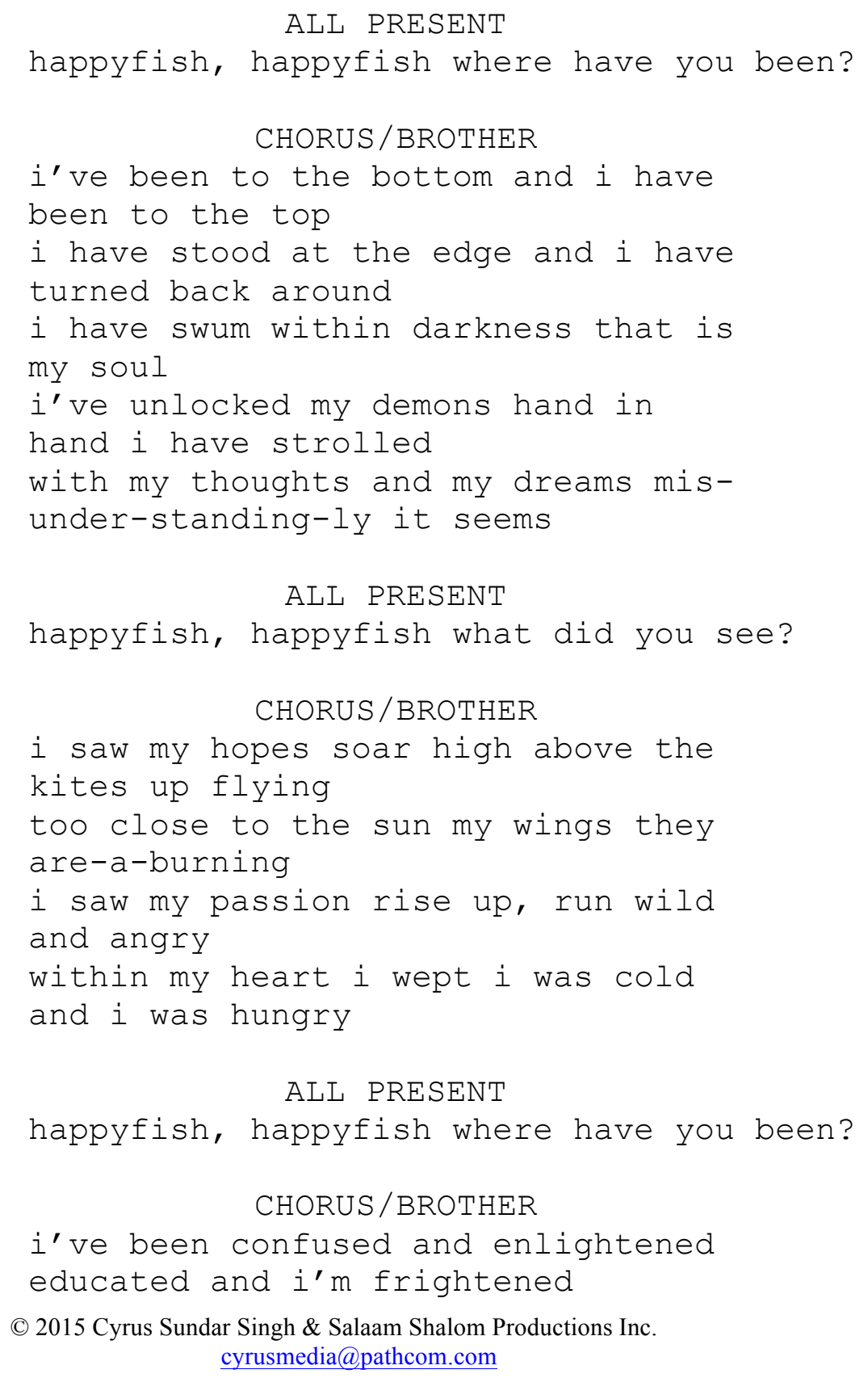




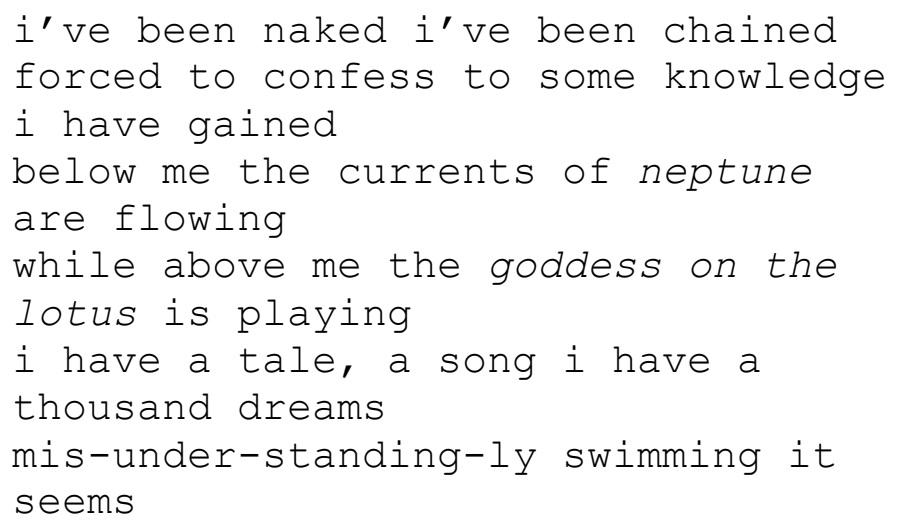

[Cue Music 31] A moment later, BROTHER begins to percussively "play" a pot, which sets up an 8-bar beat. This gets picked up by the Dolak player and then by the CHORUS of 3 dancers Mira, Gabi and Dharshi. They enter the Café - scat-singing (TaKaDiMi): Gabi enters from stage Left. Mira enters from stage Right. Dharshi enters from the Kitchen. The camera-crew re-position to better cover the dancers. The dance ends with a percussive flourish. The CHORUS breakaway creating a space in the centre for the BROTHER who steps out from behind the kitchen counter, walks up the created space and addresses the audience 
CREDITS: BROTHERS IN THE KITCHEN

A documentary by

Cyrus Sundar Singh

Director: Cyrus Sundar Singh

Producer: Cyrus Sundar Singh

Executive Producer: Vanessa Laufer

Co-Producer: Irene Armit

Narrator: Brother

Anand Rajaram

Tamil Chorus: Kattyiakkri-Gals

Gabriella Sundar Singh

Mirabella Sundar Singh

Priyadharshini Vara

Cooks: Sisters

Suseela Ramanathan

Sasi Bala

Singer:

Mathusha Kugathsan

Choreographer:

Sudharshan Durayappah

Editor: Irene Armit

Composers:

lan de Souza

Cyrus Sundar Singh

Musicians:

Ian de Souza: Bass

Jeetu Parkash: Bansuri

Santosh Naidu: Tabla/Dolak/Gangeera

Cinematographers:

Shay Schwartzman

Ted Overton

Tamas Wormser

Poster \& Postcard Design:

Saskia Laufer

Sound:

Brendan Koen

Sound \& Lights Assist:

Shaughna Boara

Subjects (in order of appearance):

Amarnath Amarasingam

Sri Guggan

Manjula Selvarajah

Sunthar Umasuthan

Kiruthiha Kulendrien

Anonymous

Shanmuga Paul

Suresh

Princy Gurusinghe

Asanka Gurusinghe

Barbara Hall

Frances Harrison

Bob Rae

Special Thanks to:

Ravi Subramaniam

Shane Smith

Sarafina DiFelice

Marc Glassman

Don Snyder

Blake Fitzpatrick

Katy McCormick

Richard Lachman

Saskia Laufer

Vid Ingelevics

Isaac Meyer Odell

Ryerson University

Mohamed Lachemi

Jennifer Mactavish

Charles Falzon

Chris Evans

Denise O'Neil Green

Doc Now Festival

Peter Fleming

Madeline Smith

Alison Macleod

Joan Jenkinson

Gary Anandasangaree

Erik Solheim

Mark Salter

Aruna Sunaseelan

Yamuna Samuel

Ganga

Selvarajah

Danton Thurairajah 


\section{LINKS TO PRESS ABOUT BROTHERS IN THE KITCHEN}

1) Brothers In The Kitchen at Hotdocs

2) $C B C$ News - A look at Tamil immigration in Toronto

3) Now Magazine by Rad Simonpillay

https://nowtoronto.com/movies/hot-docs-2016/brothers-in-the-kitchen/

4) Published on May 12, 2016 by Corey Mintz (food writer for the Globe \& Mail) , Special to TVO.org

What it's like to be a Tamil refugee in a Toronto kitchen

http://tvo.org/article/current-affairs/shared-values/what-its-like-to-be-a-tamil-

refugee-in-a-toronto-kitchen

5) from IDA:

http://www.documentary.org/online-feature/canadian-docs-thrive-their-home-turfhot-docs

6) http://www.cbc.ca/beta/news/canada/toronto/programs/metromorning/buying-

a-lifeboat-1.3736715

7) https://cinemaaxis.com/2016/03/22/diverse-stories-shine-at-hot-docs/

8) http://www.24news.ca/entertainment/210749-hot-docs-festival-will-bring-newtechnologies-hybrid-storytelling-forms-to-toronto

9) http://www.examiner.com/article/hot-docs-full-line-up-announced

10) http://realscreen.com/2016/03/22/league-of-exotique-dancers-to-open-hotdocs/

11) http://www.theglobeandmail.com/arts/film/hot-docs-festival-will-bring-newtechnologies-hybrid-storytelling-forms-to-toronto/article29328460/

12) http://boxoffice.hotdocs.ca/websales/pages/list.aspx?epguid=7d40538f-b78742db-b800-e5d6075294ae\&perpage =13\&cp268=Highlight \&

13) https://twitter.com/hotdocs 
This letter of recommendation is written in support of Cyrus Sundar Singh, a singular talent and visionary artist whom I had the pleasure of working with at Hot Docs Canadian and International Documentary Festival this year.

Cyrus premiered his unique site specific documentary project BROTHERS IN THE KITCHEN at Hot Docs 2016, to resounding critical and audience success. When pitching the project, Cyrus won over the Hot Docs team with his vision, passion and intelligence. His idea to develop, produce, perform (and content capture) a live event as complex as BROTHERS IN THE KITCHEN seemed daunting, but we put our faith and trust in Cyrus, and he more than delivered.

BROTHERS IN THE KITCHEN is a site specific documentary hybrid performed live inside a fully operational restaurant and it follows the story of the Tamil Sri Lankans who fled a brutal civil war and sought refuge in Canada. Pushing the boundaries of documentary storytelling in fascinating new ways, by incorporating elements of music, poetry and dance (and including the participation of high-profile political figures Bob Rae and Barbara Hall), BROTHERS IN THE KITCHEN truly was a feast for the mind, body and soul.

Once the project was invited to participate in Hot Docs 2016, Cyrus worked tirelessly to bring it to life. He was a superb collaborator, taking Hot Docs suggestions on board, working within budgets, and finding inventive ways to bring additional resources to the table while maintaining his creative vision for the project. Cyrus mobilized his community and his colleagues (not to mention his willpower!) to bring the project to life, ensuring that it maintained a strong sense of authenticity while remaining theoretically grounded in the experiences of those who lived through the events depicted.

Once announced, BROTHERS IN THE KITCHEN gained immediate attention, and it was one of the first events at Hot Docs to sell out. It garnered great media attention from outlets including CBC Radio, TVO.org, NOW Magazine and the International Documentary Association. The evening of the premiere was an incredibly special night, and audiences were engaged, inspired, stunned and moved by the events that unfolded in front of them. I personally received several emails congratulating Hot Docs for supporting such a bold and unique documentary storytelling event.

A rare artist who can combine creativity with practical considerations in pursuit of excellence, Cyrus Sundar Singh can be counted on to deliver immersive, innovative experiences with integrity and intelligence.

Sincerely,

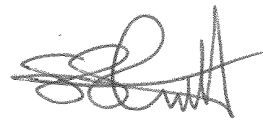

Shane Smith

Director of Programming, Hot Docs 


\section{Brothers in the Kitchen - Production Schedule Revision 3.0 March to May 2016}

\begin{tabular}{|c|c|c|}
\hline Date: & Action: & Notes: \\
\hline 3 March & Talent Meeting & CSI Annex \\
\hline 4 March & Tech Meeting: Tech Treatment & $\begin{array}{l}\text { Crew (Ted, Shay, Adam, Shaughna, } \\
\text { Irene, Cyrus) CSI Annex }\end{array}$ \\
\hline 7 March & Script Outline Final :Begin Script Drafts & Cyrus \\
\hline 10 March & Production meeting with crew & $\begin{array}{l}\text { Crew Ryerson (meeting room TBD) } \\
9 \text { am with Ted and Shay } \\
10 \text { am Adam and Shaughna join }\end{array}$ \\
\hline 13 March & Choreography/ Rehearsal & Cast - 9am CSI 720 Bathurst St \\
\hline 14 March & Script Draft 1 & Cyrus \\
\hline 17 March & Production Meeting & $\begin{array}{l}\text { Ryerson - } 10 \text { am- } 1 \mathrm{pm} \\
\text { Second floor of the RCC ( } 80 \text { Gould) } \\
\text { in the TMZ - Screening Room } \\
\text { RCC } 240 A \\
\text { Crew Cyrus, Ted, Shaughna, Shay, } \\
\text { Irene }\end{array}$ \\
\hline $21 \mathrm{March}$ & $\begin{array}{l}\text { Script Draft 2: Finalize Interview Subjects } \\
\text { Music Collaboration }\end{array}$ & $\begin{array}{l}\text { Cyrus } \\
\text { lan } 3 p m\end{array}$ \\
\hline 24 March & Rough Cut 1 : Production Meeting & Irene/Cyrus Ryerson \\
\hline 31 March & Rough Cut 2:Production Meeting & $\begin{array}{l}\text { Start CSI 9:30am } \\
\text { Move to Ryerson PM - Equipment } \\
\text { Tests } \\
\text { 9:30am - } 3 \text { pm } \\
\text { Crew Cyrus, Ted, Shaughna, Shay } \\
\text { Irene }\end{array}$ \\
\hline 3 April & $\begin{array}{l}\text { Choreography/ Rehearsal (Tentative - } \\
\text { email to follow) }\end{array}$ & $\begin{array}{l}\text { Cast - CSI - Gabi, Mira, Anand, } \\
\text { Sudharshan }\end{array}$ \\
\hline 7 April & Production Meeting: Fine Cut & $\begin{array}{l}\text { Irene/Cyrus 1-468 Brunswick Ave } \\
\text { 10am }\end{array}$ \\
\hline
\end{tabular}




\begin{tabular}{|c|c|c|}
\hline 8 April & Rehearsal - Chorus & $\begin{array}{l}\text { Cast - 3pm- } 5 p m \\
\text { Mira, Sudharshan, Anand } \\
\text { Ryerson University } \\
\text { Dance Studio S54 } \\
\text { Kerr Hall South, } 40 / 50 \text { Gould Street }\end{array}$ \\
\hline 14 April & Production Meeting :Music Compose & 1-468 Brunswick Ave \\
\hline 15 April & Rehearsal - Chorus & $\begin{array}{l}\text { Cast - 3pm- 5pm } \\
\text { Mira, Sudharshan, Anand } \\
\text { Ryerson University } \\
\text { Dance Studio S54 } \\
\text { Kerr Hall South, } 40 / 50 \text { Gould Street }\end{array}$ \\
\hline 21 April & Production Meeting & Crew TBD \\
\hline 22 April & Rehearsal - Chorus & $\begin{array}{l}\text { Cast - 3pm- 5pm } \\
\text { Mira, Sudharshan, Anand } \\
\text { Ryerson University } \\
\text { Dance Studio S54 } \\
\text { Kerr Hall South, } 40 / 50 \text { Gould Street }\end{array}$ \\
\hline 28 April & Production Meeting & Crew TBD \\
\hline 29 April & Rehearsal - Chorus & $\begin{array}{l}\text { Cast - 3pm- } 5 p m \\
\text { Mira, Sudharshan, Anand } \\
\text { Ryerson University } \\
\text { Dance Studio S54 } \\
\text { Kerr Hall South, } 40 / 50 \text { Gould Street }\end{array}$ \\
\hline 30 April & Tech Run Through -Script Run, TV Install & CSI - All Cast and Crew \\
\hline 1 May & Tech Run Through- All Day - Script Run & CSI - All Cast and Crew \\
\hline 2 May & Tech Run Through - Evening & CSI - All Crew \\
\hline 4 May & Delivery : Documentary Premiere & $\begin{array}{l}\text { CSI - All Cast and Crew } \\
2 \mathrm{pm} \text { crew arrives \& begin set up } \\
5 \mathrm{pm} \text { sound and lights check } \\
\text { 6pm Hot Docs Personnell } \\
\text { 6:30pm Doors Open } \\
8 \mathrm{pm} \text { Documentary Begins }\end{array}$ \\
\hline
\end{tabular}




\section{BIBLIOGRAPHY}

Amarasingam, Amarnath. "Pain Pride, and Politics: Social Movement Activism and the Sri Lankan Diaspora in Canada." University of Georgia Press.

(Athens: Georgia, 2015). And Tamil Tigers, in CBC News online, April 20, 2009 http://www.cbc.ca/news/canada/tamiltigers-1.783483 and

Bradshaw, Peter. "The Arbor- review." In The Guardian. October 21, 2010 https://www.theguardian.com/film/2010/oct/21/the-arbor-film-review

Bruzzi, Stella. "The Performative Documentary: Barker, Dineen, Broomfield." In New Documentary: A Critical Introduction Florence, US: Routledge, 2000.

Coykendall, Bruce. "Sony Dsr-Pd150 Dvcam Camcorder Review." In Videomaker Magazine, May 2002. https://www.videomaker.com/article/c5/8869-sony-dsrpd150-dvcam-camcorder-review

deLahunta, Scott. "Sniffable Media." In Performance Research 8 (3) doi:10.1080/13528165.2003.10871948 (Routledge, 2003) 85 http://resolver.scholarsportal.info/resolve/13528165/v08i0003/85 sm

Ebert, Roger. "Nanook of the North" review in RogerEberg.com. September 25, 2005. http://www.rogerebert.com/reviews/great-movie-nanook-of-the-north-1922

Glaser, Barney G. and Strauss, Anselm. The Discovery of Grounded Theory: strategies for qualitative research (New York: Aldine Pub. Co., 1967)

Halprin, Lawrence. The RSVP Cycles: Creative Processes in the Human Environment. (New York: Braziller, Inc., 1969).

Loxton, Charles. "Albert Maysles (1926-2015) Pushed Documentary Filmmaking Forward to the Very End." in Browbeat Magazine Slate's Culture Blog, online March 7, 2015 http://www.slate.com/blogs/browbeat/2015/03/06/albert maysles dead grey gardens director pushed documentary filmmaking.html

Markham, James. "German Captain Denies Role in Tamils' Journey." Special to the New York Times, August 17, 1986. http://www.nytimes.com/1986/08/17/world/german-captain-denies-rolein-tamils-journey.html

McAlpine, Alison. "Robert Lepage in conversation with Alison McAlpine." In Contact With The Gods? edited by Maria M. Delgado and Paul Heritage (Manchester: Manchester University Press 1996), 134 
"Migrant crisis: Migration to Europe explained in seven charts" in BBC News Online, March 4, 2016 http://www.bbc.com/news/world-europe-34131911 downloaded August 28, 2016

Mintz, Corey. "What it's like to be a Tamil refugee in a Toronto kitchen," in TVO's Current Values/Shared Values, published May 12, 2016.

http://tvo.org/article/current-affairs/shared-values/what-its-like-to-be-a-tamilrefugee-in-a-toronto-kitchen

O'Donnell, Catherine. "New study quantifies use of social media in Arab Spring." In UWTODAY, University of Washington, September 12, 2011. http://www.washington.edu/news/2011/09/12/new-study-quantifies-use-of-socialmedia-in-arab-spring/

O'Donnell, Joe. "Show compassion for Tamil refugees Mulroney urges" in Toronto Star August 18, 1986 (ProQuest-Canadian Newsstand).

Paget, Derek. 2010. Acts of Commitment: Activist Arts, the Rehearsed Reading, and Documentary Theatre. (Cambridge University Press: May 2010) 188

Parkinson, Hilary. "The true story behind the Gettysburg sharpshooter." In The National Archives, June 20, 2013. https://prologue.blogs.archives.gov/2013/06/20/thetrue-story-behind-the-gettysburg-sharpshooter/

Patrick, Caitlin and Kennedy, Liam. The Violence of the Image: Photography and International Conflict, edited by Liam Kennedy and Caitlin Patrick (London \& New York: I.B.Tauris 2014)

Ponnuchami, Selva. "Tamil Journeys '86." In Monsoon Journal. Edited by Logan Velumailum, July 2016. p18-19 https://issuu.com/monsoonjournal/docs/mj_july_2016 web

$\mathrm{R}$, Cheran. "Diaspora Circulation And Transnationalism As Agents For Change In The Post Conflict Zones Of Sri Lanka." Department of Sociology and Centre for Refugee Studies, York University (Toronto York University Press, 2003).

R, Cheran and Aparne Halpé. "On Responsible Distance: An Interview with R, Cheran by Aparne Halpé." University of Toronto Quarterly, Volume 84, Number 4, Fall 2015, pp. 90-108 (Article)

Raby, Gyllian. "Improvisation and Devising: The Circle of Expectation, the Invisible Hand, and RSVP." In Canadian Theatre Review, vol 143, Summer 2010 pp 94 97 (Article) Toronto: University of Toronto Press. 
Rich, Alysse. "Reconfiguring the Chorus: Adaptations of the Greek Tragic Chorus since World War II." PhD diss., University of Toronto, 2012.

Renov, Michael. "Toward a Poetics of Documentary." In Theorizing Documentary, edited by Michael Renov (New York: Routledge, 1993), 26.

Sandercock, Leonie. "The Quest for an Inclusive City: An Exploration of Sri Lankan Tamil Experience of Integration in Toronto and Vancouver." University of British Columbia [electronic resource] (British Columbia: Metropolis, 2004), 12-13.

Simonpillai, Radheyan. "Brothers In The Kitchen Serves Up Moving Stories At Hot Docs: Interactive Hot Docs Festival show puts the Tamil immigrant issues on the menu" in NOW MAGAZINE, May 6 2016. https://nowtoronto.com/movies/hotdocs-2016/brothers-in-the-kitchen/

Simmons, Odis E. 2006. "Some Professional and Personal Notes on Research Methods, Systems Theory, and Grounded Action." In World Futures 62 (7): 481 490.doi:10.1080/02604020600912772.http://resolver.scholarsportal.info/resolve/0 2604027/v62i0007/481 spapnomstaga.

Soans, Robin. In Verbatim, verbatim: contemporary documentary theatre, edited by Will Hammond \& Dan Steward (London: Oberon, 2008) 21

Spurlock, Morgan. In Super Size Me, a documentary film starring Morgan Spurlock. https://www.youtube.com/watch?v=jAnCOHCVjyU

Story, Alan and Hall, Joseph."152 castaway paid thousands to flee to Canada", in Toronto Star, August 12, 1986.

Sullivan, Bill. "The Real Thing: Photographer Luc Delahaye", in Artnet, October 4, 2003. http://www.artnet.com/magazine/features/sullivan/sullivan4-10-03.asp, and

Sundar Singh, Cyrus. "Soldat du Fortune." In Filling in the Blanks: Essays on Art, Media and Culture.Media Writing Fall, 2014, Ryerson University. edited by Michele Clarke. (Toronto: Ryerson University, 2014) 297

Valpy, Michael. "Strangers by sea: A tale of Canada's boat people." in The Globe and Mail, August 13, 2010. http://www.theglobeandmail.com/news/politics/strangersby-sea-a-tale-of-canadas-boat-people/article1377063/

Van Cooten, Narissa. "Africville in Black and White To Premiere At b current's rock.paper.sistahz Festival", In Pride Magazine, May 2, 2016 http://pridenews.ca/2016/05/02/africville-black-white-premiere-b-currents-rockpaper-sistahz-festival/ 
Winston, Brian. ETHICS, p181, Alan Rosenthal, John Corner Manchester University. (Manchester, UK: Manchester Press, 2005).

Wyer, Malcolm "Meta-Documentary of a Meta-Documentary" in The Brooklyn Rail. (July 2009). http://www.brooklynrail.org/2009/07/film/meta-documentary-of-ameta-documentary 


\section{WORKS CONSULTED}

Aufderheide, Patricia. Documentary Film: A Very Short Introduction (New York: Oxford, 2007)

CBC TELEVISION: The archives at CBC TV: There are hundreds of hours of archival news footage of the 1986 arrival of the Tamil boatpeople and other related material.

Chapman, Jane. Documentary In Practice (Cambridge UK: Polity Press, 2007)

Chanan, Michael. The Politics of Documentary (London: British Film Institute, 2007)

Cohen, Thomas F. Playing to the camera: musicians and musical performance in documentary cinema (London; New York : Wallflower, 2012)

de Haan \& Brummelen, Van. Episode Of The Sea (2014)

Douglas, Stan. Abbott \& Cordova, 7 August 1971 (Vancouver: Arsenal Pulp Press, 2011)

Douglas, Stan. Mise en Scene, edited by Leon Krempel and Verlagsgyuppe Prestel (New York: Random House, 2014)

Douglas, Stan; Past Imperfect- Works 1986-2007, edited by Hans d. Christ, Iris Dressler and Hatje Cantz Verlag (Germany 2008)

Francis, Douglas R., Jones, Richard, Smith, Donald B., and Wardburg, Robert A. Destinies: Canadian History since Confederation (Toronto: Nelson, 2012)

Greyson, John. Perlis of Pedagogy, The: The works of John Greyson, edited by Brenda Longfellow; Scott MacKenzie and Thomas Waugh, McGill-Queens University Press 2003

Harney, E.D., Robert, F. Toronto's People. Polyphony, Multicultural History Society of Ontario, 1984. Print.

Harrison. F. Still Counting the Dead: The untold story of Mullivaikkal (London: House of Anansi, 2012)

Jacobs, Lewis. The Documentary Tradition: From Nanook to Woodstock, edited by Lewis Jacobs (New York: Hopkins and Blake, 1971)

Maddin, Guy. My Winnipeg (Toronto: Coach House Books, 2009) 
Marchessault. Janine., Lord. S. Fluid Screens, Expanded Cinema (Toronto: University of Toronto Press, 2008)

Marcus, Dara. The Hai Hong incident: One boat's effect on Canada's policy towards Indochinese refugees. University of Ottawa. N.D. IMRC and CIHS Submission. WEB

Nichols, Bill, (2008),“Documentary Reenactment and the Fantasmatic Subject,” Critical Inquiry 35 (Autumn).

Ondaatje, Michael. Anil's Ghost (Toronto: McClelland \& Stewart, 2000)

Salter, Mark. To End A Civil War: Norwary's Peace Engagement in Sri Lanka (London: C Hurst \& Co, 2015).

Saunders, Doug. Arrival City: The Final Migration and Our Next World (Toronto: Knof Canada, 2010)

Subramanian, Samanth. This Divided Island: Life, Death, and the Sri Lankan War (New York: St. Martin's Press, 2014).

Toronto Star: Archives. From August 1986, the Toronto Star has been writing articles about the Tamils "boatpeople". There are plenty of historical and current articles to research.

"Vinland" Visited About The Year 1000 By "Leif The Lucky." New York Times (1857-1922); Feb 9, 1890; ProQuest Historical Newspapers: The New York Times. P11 http://www.livescience.com/37189-new-viking-voyagediscovered.html

Wahlberg, Malin. Documentary Time: Film and Phenomenology (Minneapolis: University of Minnesota Press, 2008)

Waugh, Thomas (2011). "Acting to Play Oneself: Performance in Documentary (1990)." In Acting to Play Oneself: Looking Back on Documentary Film. Visible Evidence Series, Vol. 23. Minneapolis: University of Minneapolis

Waugh, Thomas. The Right To Play Oneself" looking Back on Documentary Film Phenomenology (Minneapolis: University of Minnesota Press, 2011)

Weiss,Gordon. The Cage: The fight for Sri Lanka \& the Last Days of the Tamil Tigers (London: The Bodley Head, 2011) 